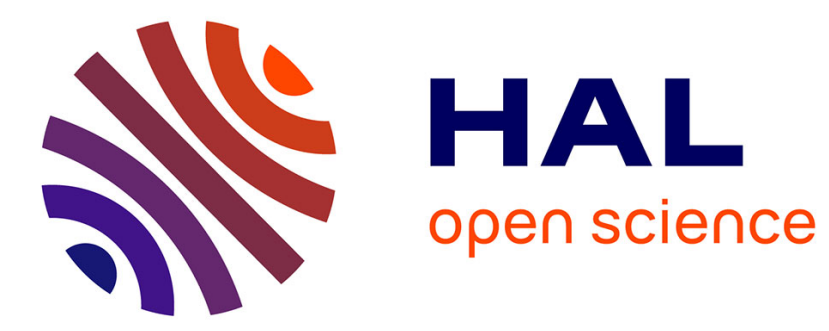

\title{
Quaternary sediment dispersal in the Zambezi turbidite system (SW Indian Ocean)
}

\author{
Ruth Fierens, Samuel Toucanne, Laurence Droz, Gwenael Jouet, François \\ Raisson, Elisabeth Jorissen, Germain Bayon, Jacques Giraudeau, Stephan \\ Jorry
}

\section{To cite this version:}

Ruth Fierens, Samuel Toucanne, Laurence Droz, Gwenael Jouet, François Raisson, et al.. Quaternary sediment dispersal in the Zambezi turbidite system (SW Indian Ocean). Marine Geology, 2020, 428, pp.106276. 10.1016/j.margeo.2020.106276 . hal-02992198

\section{HAL Id: hal-02992198 https://hal.science/hal-02992198}

Submitted on 6 Nov 2020

HAL is a multi-disciplinary open access archive for the deposit and dissemination of scientific research documents, whether they are published or not. The documents may come from teaching and research institutions in France or abroad, or from public or private research centers.
L'archive ouverte pluridisciplinaire HAL, est destinée au dépôt et à la diffusion de documents scientifiques de niveau recherche, publiés ou non, émanant des établissements d'enseignement et de recherche français ou étrangers, des laboratoires publics ou privés. 


\section{Quaternary sediment dispersal in the Zambezi turbidite system (SW Indian Ocean)}

Article in Marine Geology · June 2020

DOI: $10.1016 /$ j.margeo.2020.106276

CITATIONS

9 authors, including:

Ruth Fierens

Université de Bretagne Occidentale

8 PUBLICATIONS 20 CITATIONS

SEE PROFILE

L. Droz

French National Centre for Scientific Research

147 PUBLICATIONS 2,506 CITATIONS

SEE PROFILE
READS

113

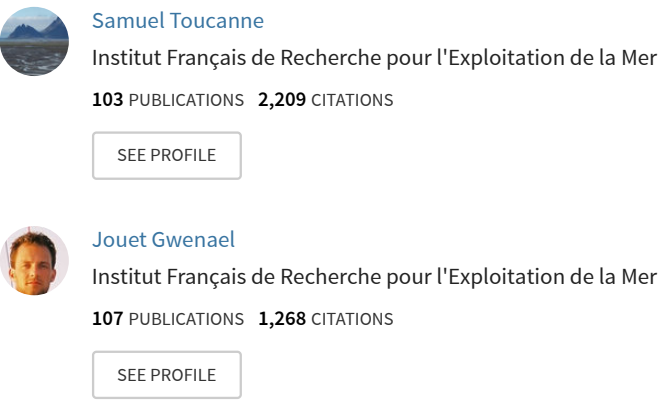

Some of the authors of this publication are also working on these related projects:

Project $\quad$ Modeling sediment supply of the Congo watershed since the last 155 ka View project

Submarine landslides in the Northern Tyrrhenian Sea and relationship with the contouritic and turbiditic deposits: morphology, stratigraphy, geotechnics and modelling View project 


\section{Journal Pre-proof}

Quaternary sediment dispersal in the Zambezi turbidite system (SW Indian Ocean)

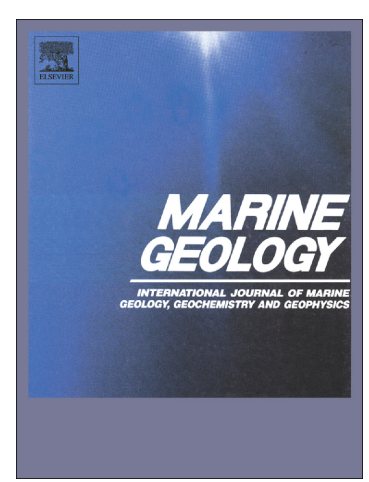

Ruth Fierens, Samuel Toucanne, Laurence Droz, Gwenael Jouet, François Raisson, Elisabeth L. Jorissen, Germain Bayon, Jacques Giraudeau, Stephan J. Jorry

PII: $\quad$ S0025-3227(20)30164-X

DOI: $\quad$ https://doi.org/10.1016/j.margeo.2020.106276

Reference: $\quad$ MARGO 106276

To appear in: $\quad$ Marine Geology

Received date: $\quad 19$ December 2019

Revised date: $\quad 9$ June 2020

Accepted date: $\quad 14$ June 2020

Please cite this article as: R. Fierens, S. Toucanne, L. Droz, et al., Quaternary sediment dispersal in the Zambezi turbidite system (SW Indian Ocean), Marine Geology (2020), https://doi.org/10.1016/j.margeo.2020.106276

This is a PDF file of an article that has undergone enhancements after acceptance, such as the addition of a cover page and metadata, and formatting for readability, but it is not yet the definitive version of record. This version will undergo additional copyediting, typesetting and review before it is published in its final form, but we are providing this version to give early visibility of the article. Please note that, during the production process, errors may be discovered which could affect the content, and all legal disclaimers that apply to the journal pertain.

(C) 2020 Published by Elsevier. 


\title{
Quaternary sediment dispersal in the Zambezi turbidite system (SW Indian
}

\section{Ocean)}

\author{
Ruth Fierens ${ }^{\mathrm{a}^{*}}$, Samuel Toucanne ${ }^{\mathrm{b}}$, Laurence Droz ${ }^{\mathrm{a}}$, Gwenael Jouet ${ }^{\mathrm{b}}$, François Raisson ${ }^{\mathrm{c}}$, Elisabeth L. \\ Jorissen $^{\mathrm{a}, \mathrm{d}}$, Germain Bayon ${ }^{\mathrm{b}}$, Jacques Giraudeau ${ }^{\mathrm{e}}$ \& Stephan J. Jorry ${ }^{\mathrm{b}}$ \\ a IUEM-UBO-CNRS, UMR6538, La boratoire Géosciences Océan, 29280 Pl ouzané, France. \\ bIFREMER Centre Bretagne, Unité de Recherche Géosciences Ma rines, 29280 Plouzané, . rance. \\ ${ }^{\mathrm{c}}$ Total, Centre Scientifique et Technique Jean Féger, 64000 Pau, France \\ d Present a ddress: Utrecht University, Department of Earth Sciences, Budapestl، эn 17 3584 CD Utrecht, The Netherlands \\ e EPOC, UMR 5805, Université de Bordeaux, CNRS, 33615 Pessac CEDEX, F u. -e
}

*Corresponding author: Ruth.Fierens@univ-brest.fr

\begin{abstract}
This study investigates the Late 2u.ternary sediment distribution of the Zambezi turbidite system (Mozambique Channel, Western 'ndian Ocean) from a set of piston cores that characterizes the sedimentation in the 'te me liate Basin and in the proximal and distal parts of the Zambezi Fan. Sedimentological and gi-chemical analyses permit to define variations in sediment composition, sediment accumulation rates and timing of turbiditic deposits over the past $720 \mathrm{kyr}$. Our study reveals low sediment inputs and rare turbiditic deposits in the Zambezi turbidite system, and the de ep (>2,500 m) Mozambique Channel in general, over the studied time interval. The reconstruction of the terrigenous fluxin the upper part of the system suggests monsoon-related precipitation changes as the main forcing for riverine inputs variability in the Zambezi system. However, the occurrence of turb iditic deposits in the cores suggests that there is no genetic link between the ir triggering and evolving climate
\end{abstract}


and sea-level conditions, thus emphasizing transformation of failed (slide-generated) sediment from the continental slope as the main initiation process for turbidity currents in the Zambezi system. Finally, our data highlight regional-scale changes in sedimentary facies through time, interpreted as successive 'onoff' switches in the activity of the distal Zambezi Fan, and by extension, regional-scale depocenter shifts. The last one likely occurred at $350 \pm 42 \mathrm{kyr}$, and is concomitant with a significant increase in terrigen ous inputs into the proximal Intermediate Basin. It is speculated that this depocenter shift is related to a major southward migration of the Zambezi delta.

Keywords: Zambezi turbidite system, Mozambique Channel cimate changes, monsoon, Quaternary, depocentershift

\section{Introduction}

Turbidite systems are currently a major : xcus of industry and academic research because they are targets for oil and gas exploration 'Chä ^r ıugam and Moiola, 1988; Weimer and Link, 1991; Clark and Pickering, 1996; Stow and Mayaii, 200u; Pettingill and Weimer, 2002; Mayall et al., 2006; Howell et al. 2014; Fonnesu et al, 2020) an. ' c n hold a potential record of past terrestrial environmental changes (Hesse and Khodabakh_'. . 998 ; Bouma, 2001; Piper et al., 2007; Clift et al., 2008; Ducassou et al., 2009; Toucanne et al., 2008, 2012; Covault et al., 2010; Jorry et al., 2011; Bonneau et al., 2014). The main forcing factors that influence sedimentary distribution and flux in turbidite syste ms (tectonics, climate, sea-level, hydrodynamics, deep currents, etc.) have been identified for a long time, though their exact role and interplay remains debated (see Hinderer, 2012 and Romans et al., 2016 for thorough reviews). Initially, the architecture and evolution of turbidite systems and, more generally, the sedimentation on the margins were globally envisioned to be mainly controlled by glacio-eustatic sea-level variations (Vail et al., 1977; Shanmugam and Moiola, 1982; Shanmugam et al., 1985). 
According to the principle of sequence stratigraphy, the turbidite system develops mainly during sealevel falls and lowstands, when the rivers, as the main source of these depositional systems, are able to reach the shelf edge and deliver sediments directly to the deep basin (e.g., Vail et al., 1977; Posamentier and Kolla, 2003). However, an increasing number of studies provide evidence s that in specific climatic conditions (at both high- and low-latitude) the growth of turbidite systems is also governed by climate that modulates the fluvial discharge and sediment flux from rivers (e.g., Covault and Graham, 2010 for a review). At high latitudes, maximal sediment ' '' Ix occurs during deglacial sealevel rise when sediment discharge increases in response to t a d cay of ice sheets (Kolla and Permuttler, 1993; Skene and Piper, 2003; Zaragosi et al., 200 ,; ı. ;, sanas et al., 2008; Toucanne et al., 2008, 2012). At lower latitudes, the intensification oi the summer monsoon during interglacial intervals results in higher water and sediment disc $1 a^{r}$ g?s to the ocean, which cause higher turbidity current activity in the deep sea despite sea-I -ve hig. stand conditions (Ducassou et al, 2009; Prins et al., 2000; Bourget et al., 2010; Liu et al., 2016; Pıot et al., 2019). Thus, climate-related changes in the seaward sediment flux strongly mor $u^{\prime} x_{\imath}$ the sea-level forcing acting on the deep-sea turbidite systems.

Despite being one of the lar ${ }^{-a c_{i}}$ turbidite systems in the world, the feeding and evolution of the Zambezi turbidite syste. $\eta$ sull remains unknown. The study of the Zambezi turbidite system started during the eighties by Kolla et al. (1980a, b), who did a regional study on the sedi ment distribution patterns and physiography. This was followed by the research of Droz and Mougenot (1987) that focused on the various evolution stages of the Mozambique Fan since the Oligocene. More recently, studies focused on the geomorphological character of the Zambezi Channel (e.g., Wiles et al. 2017a, b; Breitzke et al, 2017; Castelino et al., 2017; Flemming and Kudrass, 2018; Fierens et al., 2019), but despite increasing research efforts, the knowledge of the sedimentation in the Mozambique Channel is still very patchy. The only recent sedimentary data acquired in the Mozambique Channel are 
predominantly concentrated on the Mozambican platform, by focusing exclusively on the last glacialinterglacial transition (Just et al., 2014; Schulz et al., 2011; van der Lubbe et al., 2014). In this paper, we fill the gap between geomorphological studies (e.g., Kolla et al, 1980b; Fierens et al., 2019) and longterm geological reconstructions (Walford et al., 2005) by addressing which forcing factors contribute to the temporal distribution and depositional patterns of terrigenous sediments of the Zambezi turbid ite system over the last 720,000 years. Specifically, we have analyzed geochemical, sedimentological and stratigraphic characteristics of 11 piston cores located at five strate $c_{\xi}$ localities in the Mozambique Channel. Our results demonstrate the complexity of the Zambezi tu. hidi .e system, with a major distalto-proximal shift in depocenter at ca. $350 \mathrm{ka}$.

\section{Regional setting}

\subsection{The Mozambique Channel and th $7 . a^{\prime}$ abezi turbidite / depositional system}

The Mozambique Channel (Fig. 1) is locatea $\eta$ the western Indian Ocean between Madagascar and the southeast African coast. This north-c $1 \mathrm{ut}$ + ending basin deepens to the south from $2700 \mathrm{~m}\left(17^{\circ} \mathrm{S}\right)$ to

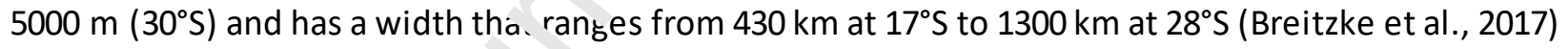

(Fig. 1A). The Mozambique $\mathrm{Ch}_{\mathrm{c}} n \mathrm{n} \geq \mathrm{l}$ formed during the break-up of the Gondwana supercontinent in Early Jurassic to Early Cre ᄂ reuus, when Africa and Antarctica continental blocks separated (Thompson et al., 2019). From Late Jurassic to Early Cretaceous, Madagascar drifted southward relative to Africa along the proto-Davie Fracture Zone to its present position (Leinweber and Jokat, 2012; Mahanjane, 2014). This breakup led to the formation of the N-S trending Davie Ridge (south of $9^{\circ} \mathrm{S}$ ) and the Mozambique and Madagascar Ridges that are located in the southern extension of the Mozambican and Madagascan margins, respectively. The central part of the Mozambique Channel is occupied by several isolated coral reef islands, namely the lles Eparses (Jorry et al., 2016) (Fig. 1B), which are inherited from 
the long-term development of carbonate platforms on top of volcanic edifices, from Oligocene to Early Miocene (Courgeon et al., 2016).

The Zambezi turbidite system covers a major part of the Mozambique Channel. The principal source of sediment to this sedimentary system is the Zambezi River (Fig. 1), which is the fourth largest river in Africa and the largest flowing into the Western Indian Ocean (Walford et al., 2005). It has a catchment area of $1.3 \times 10^{6} \mathrm{~km}^{2}$, a mean elevation of $\sim 1 \mathrm{~km}$, a total suspended sediment of $48 \mathrm{Mt} . \mathrm{yr}^{-1}$ and drains the southern part of the East African Rift System as well as the South Afr, an plateau (Thomas and Shaw, 1988; Summerfield and Hulton, 1994; Milliman and Farnsworth, 2.11) (Fig. 1). Walford et al. (2005) defined a long-term (120 Ma) record of sediment supply of the 'ar. ${ }^{h}$ _zi River towards the Mozambique margin using a two-dimensional seismic reflection survey. . ' esf authors propose a possible relationship between increasing sediment flux during Pliocene ans ar. $€$ nlargement of the Zambezi watershed area. It is important to note, however, that the $7_{\lambda} \mathrm{m}$ ez, River drainage reorganization during the Plio Pleistocene is very complex (Nugent, 1990. Thomas and Shaw, 1991; Moore and Larkin, 2001; Cotterill, 2006; Moore and Cotterill, 2010; Mooı Р $2-1$-1., 2012) and is still very much debated. In addition, the sediment flux in Southeast Africa $h_{\iota}<$ also been linked to stages of hinterland uplift that are deemed responsible for large amounts of $m_{1}$ 'ss wasting on the slope and shelf ( Green, 2011a, 2011b; Wiles et al., 2013; Hicks and Green, ?n1.'· M callef et al., 2019).

The Zambezi turbidite system consists of two different depositional systems: the Zambezi Fan (Fig. 2) and the Intermediate Basin (Figs. 1 and 3) (Fierens et al., 2019). The Zambezi Fan is characterized by the Zambezi Valley and its tributaries (e.g. Tsiribihina Valley), and by its distal distributaries and depositional area (i.e., the fan sensu stricto). The Zambezi Valley is wide, mostly rectilinear and originates in the north from the Mozambique margin (Wiles et al., 2017b). At present, the submarine valley is disconnected from the Mozambican shelf and only appears $280 \mathrm{~km}$ eastward from the Zambezi River outlet (Schulz et al., 2011; Wiles et al., 2017a; Fierens et al., 2019). The upstream part has a NW-SE orientation, which is 
transverse to the Mozambican margin. Further to the east, the Davie Ridge forms a morphological barrier making the valley change to an N-S trend (Schulz et al., 2011). The Zambezi Valley me rges with the Tsiribihina Valley, which originates from the Madagascar margin, at around $22^{\circ} \mathrm{S}$. The Zambezi Valley is included in the inner fan by Kolla et al. (1980b) (zone I in Fig. 1B). At the southern limit of the Zambezi Valley ( $\left.25.5^{\circ} \mathrm{S}\right)$, an ancient channel-levee system is identified (Fig. 2B, C; Fierens et al., 2019). Downstream of this the submarine valley ends in the Mozambique Basin where lobe deposits can accumulate (line 4, Fig. 2D) (Kolla et al., 1980b; Fierens et al., 2019). Kol ' et al. (1980b) subdivided this distal deposition area into a middle and outerfan (zone II and III in $\mathrm{Fi}_{\varepsilon}$ 1B. The middle fan is defined as the area where the valley expands into several distribution chaınt: $:$ vhere sand deposits predominate. The outer fan is located in the most distal part of the Mozaı. biq' e Basin where distributary channels are absent and where finergrained sediments are recogn ze $\iota^{\prime}$ Kolla et al., 1980b). In the study area, Kolla et al. (1980a) and Breitzke et al. (2017) recogni_ec laro?-scale seafloor bedforms, which are related to strong bottom-current influence, as also rocently , aported by Miramontes et al. (2019). Additionally, the Mozambican continental slope, the Zam $\jmath \iota_{1}$ 'alley and the lles Eparses encompasses a ponded se mi confined basin which is referred to as the Intermediate Basin (Fierens et al., 2019).

\subsection{Oceanography nu climate}

A complex and dynamic oceanic circulation pattern characterizes the MozambiqueChannel, consisting of large surface gyres and deep oceanic currents (Fig. 1A). Along the Mozambique margin, a train of deep-reaching anticyclonic eddies propagates southward. These eddies appear to be over $300 \mathrm{~km}$ wide and cause a net poleward transport of about $15 \times 10^{6} \mathrm{~m}^{3} / \mathrm{sec}$ in the upper $1500 \mathrm{~m}$ (de Ruijter et al., 2002; Schouten et al., 2003). The eastern side of the channel is characterized by temporary cyclonic eddies that move from the southern tip of Madagascar in west-southwesterly direction (Quartly and Szokosz, 2004). The deep oceanic circulation is composed of the Antarctic Bottom Water (AABW) and North 
Atlantic Deep Water (NADW) and the Antarctic Intermediate Water (AAIW). The AABW (below $4000 \mathrm{~m}$ ) and NADW (2000 m - $3500 \mathrm{~m}$ ) flow in a northward direction along the western margin of the Mozambique Channel. At $25^{\circ} \mathrm{S}$, the bathymetry becomes shallower and the AABW gets deflected towards the east and south. Similarly, the lower portion of the NADW gets deflected towards the south due to decreasing topographic depths at $20^{\circ} \mathrm{S}$. The upper part of the NADW forms together with the AAIW ( $800 m-1500 m$ ) the Mozambique Undercurrent (MUC), which has a mean northward speed of $4.6 \mathrm{~cm} / \mathrm{s}(1500 \mathrm{~m})$ and $4.5 \mathrm{~cm} / \mathrm{s}(2500 \mathrm{~m})$ (Ridderinkhof and de $\mathrm{R}_{\mathrm{t}}$ iter, 2003). This undercurrent continues flowing northwards, crosses the Davie Ridge and flows intc the jomalie Basin (de Ruijter et al., 2002; Donohue and Toole, 2003; Ridderinkhof and de Ruii er, ?2,J3; Van Aken et al., 2004; Breitzke et al., 2017).

The climate of the East Africa region is governed 'y ' ne movement of the Intertropical Convergence Zone (ITCZ). On seasonal timescales, the ITCŽ nir ates meridionally causing an equatorial zone of humid climate with a high degree of inter-anı, 'al rainfall variability. The Zambezi catchment (and the watersheds of the Madagascar rivers' _et. m.aximum preci pitation during austral summer (Dece mberFebruary) when the ITCZ boundar, migı ates to the northern half of the Zambezi Catchment (e.g., Ziegler et al., 2013).

The available terrestrial $p_{\imath}$ 'euulimate records from the African continent are often either relatively short (e.g., Talbot and Johannessen, 1992; Beuning et al., 1997, Thevenon et al., 2002; Johnson et al. 2002; Kristen et al., 2010) or long but fragmented (e.g., Barker et al., 2002; Trauth et al., 2005). These have been recently complemented by drill cores taken from long-lived lakes and paleolakes, which provide continuous records of terrestrial climate (Scholz et al., 2007; Lyons et al., 2015; Johnson et al., 2016). However, the availability of such high-resolution continental paleoclimate archives is limited and they are typically geographically dispersed (deMenocal, 2004). Hence, paleoclimate studies are commonly based on a single terrestrial or marine sediment core (e.g., Schefuß et al., 2005; Garcin et al., 2006; 
Brown et al., 2007; Lyons et al., 2015; Johnson et al., 2016; Castañeda et al., 2016). Consequently, the climate history of tropical and subtropical southeast Africa and the mechanisms that control rainfall and temperature are still highly debated.

In general, Eastern African climate is considered to have developed from warmer, wetter conditions in the Late Miocene and Early Pliocene (Cerling et al., 1997; Woldegabriel et al., 2001) towards progressively cooler and drier climate over the past few million years (Bonnefille, 1983; Cerling, 1992; Potts, 1996; deMenocal, 2004; Trauth et al., 2005). This long term chan $\xi$ towards more arid conditions is punctuated with step-like shifts in periodicity and amplitua $0^{1}$ glacial-interglacial changes. Throughout the Late Neogene the African monsoon climate var ea ${ }^{+}$, Neriodicities of 23-19 kyr (orbital precession), which was superimposed to high-latitude glac, I cyc es of $41 \mathrm{ka}$ after ca. 1.8-1.6 Ma, and of 100 ka after the Mid-Pleistocene Transition (MPT; ca. L.2 - .8 Ma) (deMenocal, 2004).

This general assumption is not supported by $n \in$ cor data from Lake Malawi $\left(10^{\circ}\right.$ to $\left.14^{\circ} \mathrm{S}, \mathrm{Fig} .1 \mathrm{~A}\right)$, the southernmost lake in the West African Rif+ Valley. This lake could persists through severe and prolonged arid periods as it is one of the deepest a Id $\mathrm{J}$ ' $\mathrm{N}$ ast lakes in the world, making possible a contin uous 1.3Myr continental record (Fig. 4; L.o, c et al., 2015; Johnson et al., 2016). Based on temperature and aridity records from Lake Malawi,, hnson et al. (2016) confirmed the 41-kyr climate periodicity prior to the Mid-Pleistocenetra 'sii on. Ifter the MPT, the environment became progressively more humid with strong 100-kyr cycles con_: ¿ing of warm, wet interglacial periods and cool, dry glacial intervals ( Fig. 4A; Johnson et al., 2016). This is supported by additional paleoclimate proxies that suggest lower lake levels with frequent water level changes before the MPT followed by overfilled lake conditions (reflecting wetter climate) that were interrupted by intervals of extreme drought until ca. $100 \mathrm{kyr}$ (Fig. 4B; Lyons et al., 2015). By correlating core results of Lake Malawi (11S) with seismic data, Scholz et al. (2007) specified that these extreme drought periods occurred during insolation minima. This is consistent with previous research on the Pretoria Saltpan in South Africa ( Fig. 4C; Partridge et al., 1997). 
These results are, in turn, partly contradicted by vegetation and hydroclimate reconstructions of the Limpopo catchment area $\left(20^{\circ}-24^{\circ} \mathrm{S}\right)$. Here, a long-term aridification was found between 1 and $0.6 \mathrm{Ma}$, followed by more-humid conditions with no evidence of the megadroughts (Fig. 4A; Castañeda et al., 2016; Caley et al., 2018). In addition to that, precipitation proxies on a core from Lake Tanganyika $\left(\sim 6^{\circ} \mathrm{S}\right)$ indicate numerous abrupt changes in hydrology throughout the past $60 \mathrm{kyr}$ (Tierney et al., 2008).

\section{Materials and methods}

\subsection{Core locations}

This study is based on 11 piston cores recovered from the Moz $\mathrm{nL}: \sim$ ie Channel between $18^{\circ} \mathrm{S}$ and $27^{\circ} \mathrm{S}$ latitude during the PAMELA-MOZ1 (Olu, 2014), PAMELA 1OZ ? (Robin and Droz, 2014) and PAMELAMOZ4 (Jouet and Deville, 2015) oceanographic crl isf.s (see Fig. 1B for piston cores location). The location of the cores was determined first 'o 0 ain the best sedimentological insight into the main physiographic margin (e.g. slope, abyssal, plain) arı ú turbidite entities (i.e., fan, Interme diate Basin) of the Mozambique Channel, from the M Iz:n rique and Madagascar slopes to the North to the deepest part of the Zambezi sedimentary sy ${ }^{+}$em to the South. Secondly, they have been retrieved from (or along) the main sedimentary and $y$ omorphological features (levees, lobes, channels, etc.) re cognized

on high-resolution mul ine $\mathrm{ma}$ Id CHIRP data (Figs. 2 and 3). The sediment cores range from 4.2 to 15.3 meters in length and ar '.ucated in water depths between ca. 2,500 and 4,400 m. Details about the cores analyzed in this study are displayed in Table 1.

\subsection{Sedimentology}

Sedimentary facies (Table 2) were described according to sediment texture and composition. For this we performed visual description, high-resolution digital photography and X-ray radiographies (Geotek-XCT system) over the entire length of the sediment cores. Additionally, grain-size analysis $(n=521)$ were 
done on selected depth intervals. Bulk samples were measured using a Mastersizer 3000 laser diffraction particle size analyser coupled to a Hydro LV wet dispersant unit. Finally, the CIE L*a*b* color indices were determined at $1 \mathrm{~cm}$ resolution by a Konica Minolta CM 2600d coupled to a GEOTEK MultiSensor Core Logger (MSCL). Acquisitions were carried out with a measurement area of $8 \mathrm{~mm}$ and using a daylight illuminant (D65) and $10^{\circ}$ viewing angle (specular component excluded), directly from the split surface of the cores. In this study, we focus on the a* parameter (red-green scale) of the spectrophotometric results, which is a good indicator for the color diffe snces occurring along the piston cores.

\subsection{Geochemistry}

In order to constrain the mechanism of color char gt in our sediment cores, we performed detailed geochemical analyses. Semi-quantitative dt ${ }^{2} r^{\prime}$, inations of geochemical profiles for major elements were acquired by an $\mathrm{X}$-ray fluorescence $\left(\mathrm{XK}_{\mathrm{r}}{ }^{-}\right)$Avaatech core scanner. Measurements were done on each piston core and performed every cen+:me or with a counting time of $10 \mathrm{sec}$. The chemical elements ( $\mathrm{Al}$, $\mathrm{Si}, \mathrm{Ca}, \mathrm{Ti}, \mathrm{Fe})$ were detected by usı. o twu acceleration voltages ( $10 \mathrm{kV}$ and $30 \mathrm{kV}$, respectively). The $\mathrm{Al} / \mathrm{Si}$ and $\mathrm{Fe} / \mathrm{Ti}$ ratios reflect variatioı.- ir sediment delivery, while the ratio of $\mathrm{Ca} / \mathrm{Fe}$ is indicative of bi oge nic primary productivity and, : $v$ extension, of past climate variability (see Richter et al., 2006; Roth well et

al., 2006; Govin et al., 2012 for thorough reviews). Additionally, quantitative determination of total $\mathrm{CaO}$ concentrations were obtained by a Bruker S8 Tiger CRF spectrometer in 10 selected sediment samples from core MOZ4-CSF20 (Zambezi slope). Both cores retrieved from the Zambezi Valley (MOZ1-KSF30 and MOZ2-KS11) were analyzed for their total organic carbon (TOC) content using the Shimadzu Total organic carbonate (TOC-L CSH) analyser with a NDIR (Non-Dispersive Infra-Red) sensor. Samples were taken with a step size of $20 \mathrm{~cm}$, dried $\left(50^{\circ} \mathrm{C}\right)$, crushed and decarbonized using $\mathrm{HCl}(4 \%)$. TOC content was calculated by subtracting the Inorganic Carbon (IC) content from the Total Carbon (TC) content. TC is 
determined on samples that underwent combustion catalytic oxidation at $680^{\circ} \mathrm{C}$ and $\mathrm{IC}$ is detected on samples that were acidificated by phosphoric acid.

Finally, 25 samples were analyzed for their Neodymium isotopic composition ( $\varepsilon N d$ ) in order to deci pher potential changes in the Zambezi River drainage reorganization through time (e.g., Tho mas and Shaw, 1991; Cotterill, 2006; Moore et al., 2012). The neodymium isotopic composition ( $\varepsilon N d$ ) of terrigenous sediment is a powerful tracer for geographical provenance because the $\varepsilon N d$ signature of detrital sediment is retained during continental weathering and subsequent transp $>r t$ (Goldstein and Jacobsen, 1988; Bayon et al., 2015). Samples were taken at selected der, cn 'ntervals on 7 cores (MOZ1-KS26, MOZ4-CS22, MOZ2-KS05, MOZ1-KSF30, MOZ2-KS11, Mn7.<KSF15 and MOZ2-KSF13). For full methodology on the sequential leaching procedure, alkalin „†t-ion and isolation of $\mathrm{Nd}$ fractions we refer to Bayon et al. (2002), Bayon et al. (2009) and Fa, in et al. (2012). Isotopic measurements were performed at the Pôle Spectrometrie Ocean, :re c(France), using a Thermo Scientific Neptune multi collector ICPMS. Mass bias corrections on Ni' were made with the exponential law, using $\left({ }^{146} \mathrm{Nd} /{ }^{144} \mathrm{Nd}\right)=$ 0.7219. Nd isotopic compositions wer $=d \epsilon$ c . mined using sample-standard bracketing, by analyzing an in-house SPEX Nd standard sol,tion (SPEX) every two samples. Mass-bias corrected values for ${ }^{143} \mathrm{Nd} /{ }^{144} \mathrm{Nd}$ were normalizen to. $C^{\prime}$ 'EX Nd value of $\left({ }^{143} \mathrm{Nd} /{ }^{144} \mathrm{Nd}\right)=0.511709$. Replicate analys es of the JNdi-1 standard solution $\mathrm{a}$ 'rıng the course of this study gave $\left({ }^{143} \mathrm{Nd} /{ }^{144} \mathrm{Nd}\right)=0.512116 \pm 0.000011$ (2SD, $n=10)$, in full agreement with reference value (0.512115) from Tanaka et al. (2000), and corresponding to an external reproducibility of $\sim \pm 0.21 \varepsilon$-units taken as the estimated uncertainty on our measurements. In this study, both measured ${ }^{143} \mathrm{Nd} /{ }^{144} \mathrm{Nd}$ ratios and literature data are reported in $\varepsilon \mathrm{Nd}$ notation $\left[\left({ }^{143} \mathrm{Nd} /{ }^{144} \mathrm{Nd}\right)_{\text {sample }} /\left({ }^{143} \mathrm{Nd} /{ }^{144} \mathrm{Nd}\right)_{\text {CHUR }}-1\right] \times 10^{4}$, using $\left({ }^{143} \mathrm{Nd} /{ }^{144} \mathrm{Nd}\right)_{\text {CHUR }}=0.512630$ (Bouvier et al., 2008). 


\subsection{Stratigraphy}

Accurate age models have been constructed for all cores based on stable isotopes (C/O), radiocarbon acceleration mass spectrometry (AMS) ${ }^{14} \mathrm{C}$ dating and nannofossil age determinations.

Foraminifera used for stable isotopes and ${ }^{14} \mathrm{C}$ datings were found along the hemipelagic layers with a sample step of 5 to $20 \mathrm{~cm}$. These hemipelagic layers are not contaminated by reworked material and represent intervals of continuous sedimentation. The samples were dried and wet-sieved at $63 \mu \mathrm{m}$. For oxygen isotope analysis about $100 \mu \mathrm{g}$ of the benthic foraminifera snocit-Cibicides wuellerstorfi were picked with a size fraction between 250 and $425 \mu \mathrm{m}$. The isot', pı cumposition was analyzed at the Leibniz Laboratory for Radiometric Dating and Stable Isotope Re_ sarch (Kiel University, Germany) using a Kiel IV carbonate preparation device connected to 7 MAT 253 mass spectrometer from ThermoScientific. During preparation the carbonate sl t.rf reacted with $100 \%$ phosphoric acid (H3PO4) under vacuum at $75^{\circ} \mathrm{C}$, and the evolved car ?n dioxide was analyzed eight times for each individual sample. All values are reported in the Vient. Pee Dee Bee notation (VPDB) relative to NBS19. Precision of all different laboratory internal ard ii to rnational standards (NBS19 and IAEA-603) is $< \pm 0.05 \%$ o for $\delta^{13} \mathrm{C}$ and $< \pm 0.09 \%$ for $\delta^{18} \mathrm{O}$ valuc . Fo i core MOZ4-CS25 the $\delta^{18} \mathrm{O}$ measurements are supported by 3 nannofossil ages. These analy_ $x$ are based on biostratigraphic and age markers from Leg ODP 175 (Shipboard Scientific Paı $\because\llcorner 998$ ). Core stratigraphy has been completed for upper core sections by Radiocarbon dating conducted on 27 selected samples (Table 3). Analyses were performed at the BETA Analytics laboratory (USA) on shells of planktic foraminifera (monospecific assemblage of G. ruber or bulk planktic foraminifera) with a fraction between 250 and $315 \mu \mathrm{m}$. Radiocarbon ages were first corrected for reservoir age and then calibrated to calendar age using the IntCal13 calibration curve (Reimer et al., 2013). Reservoir correction was inferred from radiocarbon measurements in prebomb known-age shells and coral from the tropical SW Indian Ocean (Southon et al., 2002) and calculated according to the uncalibration-convolution process of Soulet (2015), giving a current regional re servoir 
age of $426 \pm 76{ }^{14} \mathrm{C}$ years. Due to the lack of knowledge about changes of this regional reservoir age through time, this value was used to correct all ${ }^{14} \mathrm{C}$ ages of this study. Finally, the stratigraphic framework allows the calculation of linear sedimentation rates and mass accumulation rates.

\subsection{Mass accumulation rates}

Terrigenous supplies were quantified for core MOZ4-CSF20 by the calculation of the mass accumulation rates (MAR or terrigenous flux). This core was selected because of its hioh_- odimentation rates and its 'proximal' position relative to the Zambezi terrigenous sedim $=\pi$ source (see Section 5.2 ). For this purpose, the coring artefacts were first corrected based on tho L: VEMA software developed at IFREMER (Bourillet et al., 2007). The MAR, in $\mathrm{g} \mathrm{cm}^{-2} \mathrm{kyr}^{-1}$, were subse qu $n$ tly cal culated for glacial and interglacial periods according to the following formula:

$M A R=L S R * D B D *(1-$ carbonate content $)$

with LSR for Linear Sedimentation Rat $\in\left(. \mathrm{m}_{\mathrm{r}} \mathrm{r}^{-1}\right)$ and DBD for Dry Bulk Density $\left(\mathrm{g} \mathrm{cm}^{-3}\right)$. The latter has been calculated by the formula Г. $3 D-2.65 *\left(1.024-D_{\text {wet }}\right) /(1.024-2.65)$, where 2.65 equals the mean grain density (in $\mathrm{g} \mathrm{cm}^{-3}$ ) and 1. $` 4$ i: ihe interstitial water density in $\mathrm{cm}^{-3}$ (Auffret et al., 2002). The wet bulk densities $\left(D_{\text {wet }}\right)$ wer $d_{t}$-iv _d from gamma-ray attenuation density measurements.

\section{Chronostratigraphic framework}

Reliable age models for 10 cores (on 9 coring sites; see Table 1 and the associated caption) were constructed by synchronizing the $C$. wuellerstorfi $\delta^{18} \mathrm{O}$ isotopes records with the global benthic foraminiferal LR04 stack of Lisiecki and Raymo (2005) (Fig. 5). Results obtained from cores MOZ1-KS26 and MOZ4-CS22 (twin cores, i.e., taken at the same location; see Table 1) are combined to establish a composite age model, with the upper part of the record corresponding to MOZ1-KS26. In the text and 
figures that follow, we thus use the name MOZ1-KS26 to denote this composite record. For tuning, tiepoints were limited to clearly identifiable marine isotope stage (MIS) boundaries (Lisiecki \& Raymo, 2005; Railsback et al., 2015), including Terminations (i.e., glacial-interglacial transitions) (Table 4). The chronology of the uppermost portion of the cores is supported by 27 radiocarbon ages (Table 3). For core MOZ4-CS25, additional nannofossil ages were obtained at 81, 167 et $420 \mathrm{cmbsf}$ indicating MIS 12 15 (ca. $460-600 \mathrm{ka}$ ). This result is based on the acme (i.e., intervals of single species dominance of the flora) of G. caribbeanica, the presence of P. lacunose and the absence $c^{-}$R. asanoiand $H$. sellii. The age model of core MOZ4-CSF20 encompasses the last $162 \mathrm{ka}$ (i.e., core bc tor ، corresponding to mid-MIS6). Meanwhile, the age model of core MOZ2-KS05 revealed that his “ je extends back to ca. $720 \mathrm{ka}$ (MIS 18). The other seven cores register a maximum age that lie : $\urcorner$ be ween these two ages (Table 4 and Fig. 5).

The glacial/interglacial amplitude of our $\delta^{2} \cap$ sata (ca. $2 \%$ over the last 4 climate cycles) closely matches with the standard LR04 stack (Fig. -? However, the stable oxygen isotope values generally vary between 2.5 and $4.5 \%$, making the $m$ c r jistently $0.5 \%$ lower than the LR04 record. This offset is probably related to the differenı vater depths and local signature of our cores ( $3553 \pm 1052 \mathrm{~m}$ depth) with respect of the signatıre of the cores used to produce the LR04 stack (3127 $\pm 1992 \mathrm{~m}$ depth). Additionally, sediment arc'-ives recovered from the distal part (MOZ2-KSF15, MOZ2-KSF13, MOZ2-KS11 and MOZ1-KSF30) demonstrate slighter higher values per mil VPDB than cores taken in the northern part of the study area (MOZ4-CSF20, MOZ1-KS26, MOZ2-KS05 and MOZ1-KSF24). In accordance with the findings of McCave et al. (2005), this lateral variation of the benthic $\delta^{18} \mathrm{O}$ signature likely results from the different deep water masses present at these sites (AABW and NADW, respectively).

\section{Results}




\subsection{Lithofacies}

Six main sediment facies have been inferred from visual description, $\mathrm{X}$-ray radiographs and grain-size analysis (Table 2). Core MOZ4-CS21, sampled on the Zambezi slope, is predominantly composed of homogeneous dark grey silty-to sandy-clay (Fig. 6). These sediments are characterized by poor sorting, frequent inverse grading and a general bimodal grain-size distribution. Consequently, these muds solely found in core MOZ4-CS21 can be interpreted, according to Stow and Lovell (1979) and Stow and Piper (1984), as contouritic deposits, i.e., sediments deposited or substant lly reworked by the persistent action (e.g., selective deposition, winnowing, erosion) of bottom curr nts , Rebesco et al., 2014). This is supported by radiocarbon ages that suggest longer settling time, $w_{\text {: : }}$-n excludes the possibility for an instantaneous gravity flow deposit (Fig. 6). The other seci mer t cores from the Mozambique Channel consist predominantly of hemipelagic deposits (Fig 7), which are widely distributed throughout the entire study area. This facies shows significan+ ${ }^{+} \mathrm{Oo}$ )rv riability between the yellowish beige versus dark grey types, and consists of bioturbate $\gamma$ mud 'minor grain size mode $=\sim 4 \mu \mathrm{m}$ ) with abundant foraminifera (major grain size mode of $-4.5, n)$. The hemipelagic sediment at proximal sites ( MOZ4CSF20, MOZ4-CS21, , MOZ1-KS26, $V_{1} \backslash 72-K S 05$, MOZ1-KSF24 and MOZ2-KSF13) consists predominantly of olive to dark grey, foraminifera- : : (TOC) of up to $0.5 \%\left(\mathrm{Fi}_{2}-9\right.$, and a moderate to high sedimentation rate (up to $9 \mathrm{~cm} / \mathrm{kyr}$ at MOZ4-CSF 20 ;

Fig. 10). As a prominent $\epsilon$.:mple, MOZ2-KSF15 demonstrates that this hemipelagic grey facies (between $7 \mathrm{~m}$ and $10 \mathrm{~m}$ in particular in Fig. 11E, F) is enriched in iron and aluminum (relative to calcium; Fig. 11C, D) and has higher sedimentation rates (i.e., two-fold increase relative to the biogenic-dominated faci es; Fig. 11D). Yellowish beige hemipelagic deposits dominate in the distal Zambezi depositional system (e.g., cores MOZ1-KSF30, MOZ2-KS11, MOZ2-KSF15, MOZ4-CS25) (Fig. 8). It represents a 3 to $7 \mathrm{~m}$ thick sediment cover at the studied sites (Fig. 8), including MOZ1-KSF30 and MOZ2-KS11 that are retrieved on top of a levee of an ancient (i.e., non-active) channel-levee system located at the edge of the present 
Zambezi Channel (Fig. 2). This sediment is characterized by low TOC ( $0.1 \%)$ and very low sedimentation rates (<2 cm/kyr) (Fig. 9).

Hemipelagic deposits are interbedded by mainly fine-grained or massive sandy turbidites that can be easily identified by their coarseness (except at site MOZ2-KS05, see below), normal grading and distinct erosive bases (e.g., Stow \& Piper, 1984). Fine-grained turbidites (Fig. 12) have a relative widespread occurrence in the turbidite system as they are observed on the Mozambique slope (MOZ4-CSF20) and Madagascar slope (MOZ1-KSF24 and MOZ2-KSF13), in the Intermediate 'asin (MOZ1-KS26, MOZ4-CS22 and MOZ2-KS05) and on the lower Zambezi Valley flanks (MOZ1-KSF: ? an 1 MOZ2-KS11). The recurrent, fine-grained turbidite successions found at proximal sites (e.g., ... es MOZ4-CSF20 and MOZ1-KSF24) and the scarcity of turbidites in the distal Zambezi depositi רal s/stem (e.g., core MOZ2-KSF15) indicates a proximal-distal trend (Fig. 8). They are character ze $\lrcorner$ by a median (D50) grain-size of 4 to $122 \mu \mathrm{m}$ (47-122 $\mu \mathrm{m}$ for the basal part) and a ninety jer en .''e (D90) ranging from 22 to $642 \mu \mathrm{m}$ (109-642 $\mu \mathrm{m}$ for the basal part). These fine-grainec' turbidıes are interbedded within the olive to dark grey hemipelagic deposits. It is worth noti $\mathrm{g} i \mathrm{i}: \because$ in core MOZ2-KSO5 (Intermediate Basin) turbidites are remarkably finer-grained compars welsewhere, so that the turbidite beds are embedded by coarser (foraminifera-rich) hemipela oic , sies (Fig. 13). Also within the Intermediate Basin, fine-grained turbidites can occur in a sta ker configuration showing ripples with different current directions (Fig. 12). This may suggest an effec. $\mathrm{f}$ rebound and ponding processes (Remacha and Fernández, 2003; Tinterri and Muzzi Magal haes, 2011). Massive sandy turbidites (Fig. 14) are mainly observed in the deeper parts of the system, i.e., in the distal fan at sites MOZ2-KS11 and MOZ4-CS25. This may be related to an overall bypass of turbidity currents in proximal fan locations. They are interbedded in the yellowish hemipelagic facies (e.g., Fig 14). They are distinctly coarser grained with a median (D50) grain-size of 54$239 \mu \mathrm{m}$ and a ninety percentile (D90) ranging 124-689 $\mu \mathrm{m}$. Locally, two particular turbidite facies are recognized. A 14-cm thick, organic-rich turbidite (Fig. 15) is solely observed in core MOZ2-KS11. 
Secondly, carbonate turbidites (Fig. 16) are observed mainly in core MOZ1-KSF26 and MOZ4-CS22, which are located in the vicinity of the isolated carbonate platforms forming the Iles Eparses. These carbonate turbidites are originated from the shedding of Bassas da India atoll top, as previously described by Counts et al. (2018). Occasionally, thin carbonate turbiditic beds are found on the cores of Madagascar margin (MOZ1-KSF24 and MOZ2-KSF13).

\subsection{Sedimentation rates, fluxes and turbiditic deposit fremie. -ies}

Based on the age models, sedimentary accumulation rates $(S A R)$ r av been determined for each glacial and interglacial period (according to the MIS boundaries of Licię.'i \& Raymo, 2005) (Fig. 10).

Overall, for all cores, relatively low sedimentation $r=0$ s are 1 ound. SAR varies between $0.13 \mathrm{~cm} / \mathrm{ka}$ (MOZ2-KS05) and $9.64 \mathrm{~cm} / \mathrm{ka}$ (MOZ4-CSF20) and, o considerable variations are observed between glacial and interglacial periods. The data also iı, vicate a general decrease of mean sedimentation rate with increasing distance from the sou $\leadsto$ ar sas. The highest age-depth profile gradient and mean sedimentation rate $(6.1 \mathrm{~cm} / \mathrm{ka}$ ) is fo 'nd I. 'st proximal at the Mozambique margin (MOZ4-CSF20) over the past ca. $160 \mathrm{kyr}$ (Fig. 10). $\wedge$ rtı er to the south, the proximal Intermediate Basin (MOZ1-KS26) records a mean SAR close $03.7 \mathrm{~cm} / \mathrm{ka}$ during MIS 13 to MIS 1. More distally in the Intermediate Basin (MOZ2-KS05) the mean SAF value is similar over the last 243 ka (MIS 7 to MIS 1). Before (between MIS 18 to MIS 8), a very low mean sedimentation rate of $0.3 \mathrm{~cm} / \mathrm{ka}$ is found. The cores from the distal Mozambique Basin (MOZ1-KSF30, MOZ2-KS11 and MOZ2-KSF15) record average sedimentation rates close to $2.0 \mathrm{~cm} / \mathrm{ka}$ (and distinct lower profile gradients) over the past $720 \mathrm{ka}$. It is interesting to note that increased sedimentation rates (to $3.6 \mathrm{~cm} / \mathrm{ka}$ ) from 715 to $910 \mathrm{cmbsf}$ in the Zambezi lower fan site is coeval with the deposition of a Fe- and Al-rich, dark grey hemipelagicfacies (Fig. 11C to 11E). Finally, the 
cores retrieved from the Madagascar margin (MOZ1-KSF24 and MOZ2-KSF13) show mean sedimentation rates of $2.3 \mathrm{~cm} / \mathrm{ka}$ during the past ca. 350,000 yr.

The 'proximal' location of core MOZ4-CSF20, added to the high sedimentation rates (up to $\sim 10 \mathrm{~cm} / \mathrm{ka}$ ) and the recognition of the main stratigraphic $\delta^{18}$ O features (e.g., MIS 5a to MIS 5e) over the last ca. 162 ka led to quantify sediment flux (i.e., mass accumulation rates, MAR) at this site in order to explore the possible relationship existing between climate changes and terrigenous inputs over the last climate cycle (Fig. 17). The MAR shows a significant variability over the last climaticr:rlt. The results reveal that MAR ranges from 2-3 g.cm². $\mathrm{kyr}^{-1}$ during glacial intervals (MIS 2, MIS f; tu 5-/ g. $\mathrm{cm}^{2} . \mathrm{kyr}^{-1}$ during interglacials (MIS 1, MIS 5), with MAR peaks corresponding to the interol $\mathrm{zc}_{1}$ ᄀl warm intervals (i.e., MIS 5a, c and e; Fig. 17).

Finally, the sediment inputs in the turbidi+ $p_{1}$ ins have been examined through the turbidite occurrences and the calculation of the turbia. ${ }^{2}=$ frequencies (Fig. 18). For all individual cores, the duration of each isotope stage $(\mathrm{kyr})$ is di $\mathrm{I}^{\prime} \mathrm{d}_{\mathrm{n}} \mathrm{y}$ the amount of turbidites per isotope stage, thus giving turbidite recurrence times perisotc. estıze as presented through white italic numbers in figure 18. For the ease of comparison, additı naı Gaussian shaped frequency plots are constructed. Their height increases when the turbi ite irequency increases. Overall, turbidites found within the hemipelagic deposits occur irrespective of glacial or interglacial periods, i.e., intervals of high and low sea-level respectively (Fig. 18).

In the Zambezi depositional system, both proximal and distal sites indicate a low turbidites occurre nce from MIS 13 to MIS 9 (turbidite recurrence times of ca. $40 \mathrm{kyr}$ ). During the last ca. $300 \mathrm{ka}$, the turbidite activity increases at proximal sites (Zambezi slope and Zambezi Intermediate Basin sites; turbidite recurrence times of ca. $23 \mathrm{kyr}$ ) but decreases substantially (i.e., only turbidites in core MOZ2-KS11) in the distal part of the system (Zambezi Valley and Zambezi Lower Fan). During MIS 6 and 8, turbi dites in 
the Intermediate Basin (i.e., MOZ1-KS26; Fig. 12) are mainly present in a stacked configuration (i.e., one upon another) with ripples characterized by multiple directions, which may be the result of local rebounding and ponding processes (Remacha and Fernández, 2003; Tinterri and Muzzi Magalhaes, 2011).

On the other side of the Mozambique Channel (cores MOZ1-KSF24, MOZ2-KSF13), fine-grained turbidites are interbedded within the hemipelagic deposits that spans the past ca. $290 \mathrm{kyr}$ (Fig. 18). These cores register similar to slightly higher turbidite activity (average surrence time of $18 \mathrm{kyr}$ over the last 300 kyr) with a maximum activity (turbidite recurrence t, nes of ca. 10 kyr) during MIS 2-4 (MOZ1-KSF24), MIS 5 and 7-8 (MOZ2-KSF13).

\subsection{Nd isotope analysis}

$\varepsilon \mathrm{Nd}$ results are used as a proxy for changes in 'ne Zambezi drainage system (see Methods). The $\varepsilon \mathrm{Nd}$ values obtained in the hemipelagic deposits of the studied cores range from -12.2 to -20.6 ( $n=25)$ (Table

5) and the dataset show remarkable ho $n$,geneity over the last 720,000 years. Indeed, 20 of the 25 measurements give $\varepsilon \mathrm{Nd}$ values . ngir. from -13 to -15 (whatever the core location and the type of hemipelagic deposit, i.e., yellnwi-r beige versus dark grey, see below), and only two samples sh ow $\varepsilon \mathrm{Nd}$ values far from this rangt '-19.1 for MIS 1 and -20.6 for MIS 10 at sites MOZ2-KS05 and MOZ1-KSF30, respectively). The mean $\varepsilon \mathrm{Nd}$ value for the whole dataset is $-14.4 \pm 1.8$. This homogeneity suggests that there was no major drainage reorganization over the past 720,000 years.

\section{Discussion}

6.1. Tracking detrital sediment input in the Mozambique Channel and the Zambezi turbidite system 
Turbidites found along submarine channels and in deep oceanic basins can be good indicators of fluvial inputs (Normark and Piper, 1991; Piper and Normark, 2009; Covault and Graham, 2010) and of their variability over time (e.g., Covault et al., 2010; Jorry et al., 2011; Bonneau et al., 2014). The genetic link between turbidites and fluvial sources in the Mozambique Channel is emphasized by the number of turbidites that decreases with distance to the margin (see Section 5.1). This is associated to de cre asing sedimentation rates to the distal part of the Zambezi depositional system (seeSection 5.2). In addition to turbidites, hemipelagic sediment in turbidite successions signifı ntly contributes to this trend. Considering the proximity of cores MOZ4-CSF20, MOZ1-KS26, . 107 L-KSF24 and MOZ2-KSF13 to terrigenous sediment sources (i.e., Zambezi, Tsiribihina or n.ilahy rivers), we assume that suspension/transport of fluvial-derived sediment by oceanc Trap lic processes (likely including internal tides, geostrophic currents; Shanmugam, 2013, 201\&, Fdrdner et al., 2017) participates together with turbidity currents to the terrigenous sedimen+ ${ }^{+} \mathrm{t} k \mathrm{O}_{1}$, the studied margins. This has be en tho roughly discussed for the Mozambique margin and the ¿umbezi River for the past 20 kyr (van der Lubbe et al., 2014), and our data suggest that this p'o nss is effective along the Mozambique and Madagascar margins over the last glacial-interg'a乞 ${ }^{\prime}$ l cycles (at least since MIS 13 and MIS 10 at sites MOZ1-KS26 and MOZ1-KSF24, respectively; Figs. 8, : 9 and 19). The description of dark grey silty-to sandy-clay show ing bi-gradational sequen. ss it si e MOZ4-CS21 (Fig. 6, Table 2) suggests, in agreement with previous results of Kolla et al. (1S?d, b), that the terrigenous sedimentation along the Mozambique margin is impacted by bottom-currents.

Yellowish beige foraminifer ooze (see section 5.1 for their characteristics) dominates in the distal Zambezi depositional system (e.g. cores MOZ1-KSF30, MOZ2-KS11, MOZ2-KSF15, MOZ4-CS25) and is interpreted as a biogenic-dominated facies (Kolla et al., 1980a, b; Stow and Piper, 1984), constituting the background oceanic sedimentation in this region, i.e., Zambezi Fan is not receiving terrigenous sediments ("off" mode). The massive sandy turbidites (e.g., Fig. 14) present in the upper biogenic- 
dominated sequence of core MOZ2-KS11 (Fig. 8), suggest that the Zambezi Channel was fed by rare, sandy turbidity currents during the past ca. $318 \mathrm{kyr}$, producing rare levee-overbank deposits. Below the biogenic-dominated sequence of core MOZ2-KS11 (prior to ca. $318 \mathrm{kyr}$ ) the presence of olive to dark grey silty-clay sediments and organic-rich, fine-grained turbidites demonstrates terrigenous inputs that contributed to the development of this ancient channel-levee system (Fig. 9). The facies transition, from yellow- biogenic-dominated to grey-terrigenous sediment, is observed at regional scale (i.e., in cores MOZ1-KSF30, MOZ2-KS11, MOZ2-KSF15, MOZ4-CS25; Figs. 8, 18 and $\perp^{-} \uparrow$ and occurred between 437 \pm 5 ka (MOZ2-KSF15) and 318 \pm 2 ka (MOZ2-KS11), depending of the depo itio ral environments (i.e., channel edge, levee, lobes; Fig. 18). Fine-grained turbidites, interpreter as _.'-rbank deposits, are described on the levee (core MOZ1-KSF30) while thick, massive sanc.' tu bidites are found downstream at the channel outlet (MOZ4-CS25). No silty or sandy lami raf are visible in the grey silty-clay facies at core MOZ2-KSF15. However, its characteristics (cor,pc itı ? and sedimentation rates; see Section 5.1) could indicate, together with the depositional e nvironmınt, that this facies is made of stacked, base-cut-out mud turbidites (Stow and Piper, 1984) No - over, this homogeneous grey facies at core MOZ2-KSF15 (ca. $437 \pm 5$ to $508 \pm 7 \mathrm{ka}$; Fig. 18) is c 7 , mitant to the deposits of terrigenous turbidites at the other sites (i.e., cores MOZ1-KSF30 and MOZ4 -S25; Fig. 18). Hence, we could assume that it highlights terrigenous inputs in the deep Mc: эm. hiqı 2 Basin, and by extension, feeding of the distal Zambezi depositional system (i.e., Zambezi Fari : - an "on" mode due to the direct feeding of the Zambezi Valley; Fig. 19). Thus, the description of a new succession of yellow- biogenic-dominated ( 10-12 m or ca. 510-640 ka; i.e., "off" mode of the Zambezi Fan) and grey-terrigenous facies in the lower part ( $>12 \mathrm{~m}$ or $>640$ ka; i.e., "on" mode of the Zambezi Fan) of core MOZ2-KSF15 (Figs. 11 and 18) suggests a discontinuous feeding, with recurrent periods of quiescent conditions (corresponding to the yellowish beige facies; "off" mode) of the distal Zambezi system through time (Fig. 19). This is also supported by the succession of these facies in the lower part of core MOZ4-CS25 (Fig. 18), west of MOZ2-KSF15 (see Fig. 1B for locations). 
Based on the sedimentological considerations described above, a detailed reconstruction of the temporal and spatial distribution of terrigenous deposits in the Zambezi system is proposed below in Section 6.2.

Of course, the low turbidite occurrence in our piston cores does not mean that there was nearly no activity in the Zambezi turbidite system since $720 \mathrm{ka}$. The difficulty for the turbidity currents to produce overbank deposits along the very deep (ca. 700 m; Fierens et al., 2019) Zambezi Valley may be the reason why turbidites are rarely identified. Moreover, the very coarce, 'aterial present both on the deep submarine valley floors (see DSDP drilling sites 243-244; ' Ir. ?sun et al., 1974) and in the distal depositional part of the Zambezi sedimentary system (Robin anc 7roz, 2014) evidences some 'recent' activity. Since this study is based on only 11 cores taken a': $\mathrm{s} \sim$ ' cific regions of the turbidite systems, it might be anticipated that the turbidite activity may 'ia er zen significantly higher than recorded in the present study.

\subsection{Interpretation of de rita: facies in a temporal and spatial context: insights into forcing} factors

\subsubsection{Proximal depos : ion ?nvironments}

The most complete sedime ntary records in the Zambezi turbidite system are provided by deposition sites located in the vicinity of terrigenous sediment sources and are therefore the best re positories of information on timing of sediment flux from continent to ocean. Hence, we use cores MOZ4-CSF20, MOZ1-KS26, MOZ1-KSF24 and MOZ2-KSF13 to thoroughly evaluate the evolution of the detrital sedimentary inputs in the Mozambique Channel.

These sedimentary records observed in different proximal depositional environments reveal that turbiditic contributions on the margins occurred in both glacial and interglacial conditions ( see Section 
5.2) (Fig. 18). In fact, they reveal a complex, temporal pattern wherein, for example, significant turbidite activity occurred at the end of MIS 6 (max. lowstand with sea-level of $-100 /-130 \mathrm{~m}$ ) as well as at the beginning of MIS 5 ( $m a x$. highstand, sea-level of $+7 \mathrm{~m}$ ) and yet almost no turbidites appear during the Last Glacial Maximum (MIS 2, sea-level of -120 m; Grant et al., 2014; Waelbroeck et al., 2002). Thus, no substantial maximum of turbidite sedimentation is detected during glacial low sea-level periods, as currently expected. Indeed, the significant turbidity current activity observed here during interglacial sea-level highstand opposes the traditional sequence-stratigraphic i, erpretations that predict more turbidity current activity during sea-level fall and lowstand becaus ? of fluvial incision and increased fluvial transport to the marine basin (Posamentier and Vail, 1 188, " „ Jlla and Perlmutter, 1993, Piper et al., 1997). Our dataset suggests that changing sea-level cor, 'itio is do not exert a primary control on the evolution of the sediment gravity deposits in the Z:Mmbezi deep-sea turbidite system. This is in agreement with the findings of other studie, $0, h_{\mathrm{s}}$ hstand offshelf sediment transport (Boyd et al., 2008; Covault and Graham, 2010; Wiles ot al., $\angle 317$ a). It would be interesting for future research to investigate whether additional piston cc re , - -sitioned higher up the continental slope (i.e., closer to fluvial sources) show notable differeı. -e in turbiditic contributions between the glacial and inte rglacial periods or if they back up the findı zs of this study.

In order to test the possi. 'le impact of climate changes alone, in particular the effect of the southern African monsoon on the sediment delivery to the Mozambican margin, we reconstructed the terrigenous fluxes (MAR, see Section 3.5) at site MOZ4-CSF20, located northeast of the Zambezi river mouth in front of the central zone of the Mozambique continental shelf $\left(18.5-16.5^{\circ} \mathrm{S}\right)$. Contrarily to sedimentation rates (SAR), the MAR allows to put aside the biogenic carbonate fraction that is related to primary productivity, and that significantly 'pollutes' the terrigenous contribution in low sedimentation rate environments.. The MAR results reveal higher terrigenous inputs during interglacials and lower inputs during (full) glacials (see Section 5.2). This in line with the idea of dispersed northern inshore 
transfer of terrigenous material on the Mozambican platform during interglacial periods, as recently proposed by Schulz et al. (2011), van der Lubbe et al. (2014) and Wiles et al. (2017a). Moreover, this orbital-scale pattern is also visible at higher resolution, during the MIS 5, with enhanced terrigenous inputs during the warm substages (MIS 5a, $\mathrm{c}$ and e) and associated sea-level highstands (Fig. 17D). Taken together with the timing for turbiditic deposition (i.e., irrespective of glacial or interglacial periods; see Section 5.2), it confirms that sea-level conditions and the associated impact on the river-canyons connection do not solely control the continent-ocean sediment transfe, in the Mozambican margin. In contrast, our results suggest that warm conditions favored sedime $+{ }^{+}$tr nsfer at this place. Hence, we assume that our results could reflect the direct influence of the so ' 2 't ern African monso on : en hanced monsoon in SE Africa during interglacials (and low pre ossi on intervals, i.e., warm substages, in particular; e.g., Partridge et al., 1997; Simon et al , 2 J.5; Johnson et al., 2016) might have caused episodic increases of the Zambezi water disch , rgt an`' sediment load that in turn enhanced fine-grained fluvial sediment supplies towards the N'nzambıan margin. This interpretation is consistent with the monsoonal-related variability in sedime it ' $n_{1}$ '" ts observed on the Nile (Ducassou et al., 2009), Tanzanian (Liu et al., 2016), Congo (Picot et al , ¿ 19) and Ganges-Brahmaputra (Weber et al., 1997) margins.

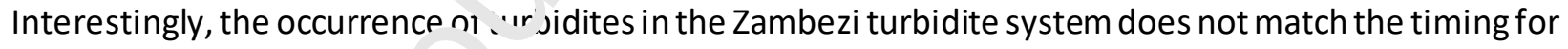
enhanced terrigenous inp. 'ts urf the Zambezi River (warm substages of the interglacial intervals; Fig. 17). Thus, based on our piston cores we may speculate that the main initiation process for turbidity currents in the Mozambique Channel is the transformation (i.e., liquefaction) of failed sediment (e.g., slides, debris flow from retrogressive failures) from the continental slope. Turbidites of the Mozambique Channel could then be interpreted as slide-generated turbidites formed by typical fully turbulent, low density, mixed sediment turbidity currents (see Piper \& Normark, 2009 for a thorough review). Massmovement features reported on the Mozambican outer shelf (Cattaneo et al., 2017) and the continental rise (Fierens et al., 2019) support this interpretation. 


\subsubsection{Distal to proximal migration of depocenter}

Distally in the Zambezi depositional system, the cores from the Zambezi Valley and Zambezi lower fan are characterized by hemipelagic dark grey silty-clay that extends from MIS 13-14 (cores MOZ1-KSF30, MOZ2-KSF15 and MOZ4-CS25) to transition MIS 10/9 (i.e. Termination 4; cores MOZ2-KS11 and MOZ1KSF30) (Fig. 18). This detrital facies, characterized by increased SAR ( 3 cm/kyr, i.e., 3-fold increase in comparison to the younger deposits) at cores MOZ1-KSF30 (Fig 9 , and MOZ2-KSF15 (Fig. 11), encompasses both warm, humid (interglacials) and cold, arid 'gla Tals) periods. At the same time, coarse, organic-rich turbidites are observed on the Zambezi Cha. nel edge (core MOZ2-KS11), spill-over deposits are found on the channel levee (core MOZ'-k_-30), and coarse sands are deposited downstream from the channel outlet (core MOZ4 C_"5) (Fig. 18). Thus, terrigenous sediment supply reached the distal parts of the Zambezi sy ${ }^{+}{ }^{+} r_{\text {, }}$ between MIS 13-14 to the MIS 10/9 transition (i.e., Zambezi Fan in a "on" mode) (Fig. 19). Ln the contrary, the abrupt change in sedimentation to a yellowish beige sediment cover at $a^{\prime \prime}$ the or distal sites after the MIS10/9 transition demonstrates the ceasing of terrigenous activity tow rds ihe distal depositional sites and, by extension, the distal Zambezi Fan (i.e. Zambezi Fan in a "oı." r.ıode) (Fig. 19). The age of 318 \pm 2 kyr at site MOZ2-KS11 (edge of Zambezi Valley) constitutı-a ıınimum age estimate for this major sedimentation change.

Interestingly, an inverse pattern is observed in the Intermediate Basin. At site MOZ2-KS05, turbiditestarved yellowish foraminifer ooze (average SAR of $0.29 \mathrm{~cm} / \mathrm{kyr}$ ) dominated until $356 \pm 42 \mathrm{ka}$ (Figs. 18 and 19) while fine-grained turbidites and the associated grey terrigenous facies (SAR of $1.96 \mathrm{~cm} / \mathrm{kyr}$ ) are deposited thereafter. In a more proximal location, core MOZ1-KS26 records a grey-terrigenous facies over the last ca. 500 ka (at least) (Figs. 18 and 19). Over this period, an increase in the turbidite frequency at site MOZ1-KS26 is observed at the same time that turbidites appeared at the distal site MOZ2-KS05 (Fig. 18). In other words, the increase of detrital inputs at MOZ1-KS26 is coeval with the 
arrival of turbidity currents and detrital inputs at MOZ2-KS05. Taken together, these observations suggest a significant increase in the detrital supplies and the eastward progradation of the depositional system in the Intermediate Basin (Fig. 19).

Importantly, the age found for the increase of turbidity current activity in the Intermediate Basin $(356 \pm 42 \mathrm{ka})$ corresponds within uncertainty to the age $(>318 \pm 2 \mathrm{ka})$ of the end of turbidity current activity, and of terrigenous supplies in general, in the deep system $\sim 490 \mathrm{~km}$ southward (Figs. 18 and 19). Therefore, a major change in the feeding of the Zambezi depositional sy tem occurred at ca. $356 \pm 42 \mathrm{ka}$. Before this date, terrigenous supplies occurred in the deep Mo: am ique Basin as well as in the (proximal) Intermediate Basin, while the Intermediate Basin $\llcorner:$ umes the unique depocenter for Zambezi-derived sediments after ca. 356 \pm 42 ka (Fig. 19).

\subsubsection{Potential causes for the depocent_ ${ }^{-s t}, \underline{\mathrm{ft}}$}

Several possible forcings may be considerec 'o explain the northward shift of the depocenter, from the distal Zambezi Fan to the Intermedinte R-sin, observed at about $356 \pm 42$ ka. Basically, this change requires the cessation of the feea.' 'g ot ihe upper Zambezi Valley and, more generally, the south ward rerouting of the Zambezi terrigt $\urcorner n$ ss flux to the Intermediate Basin. This suggests that the cause for the depocenter shift is loca 'a upstream of the upper Zambezi Valley, either at the continent-ocean transition (i.e., from the Zambezi alluvial plain to the continental shelf) or in the Zambezi catchment. Consequently, deep-sea forcings such as tectonic movements (e.g., through active faulting; Deville et al., 2018), sedimentological modifications (e.g., modification of sediment routing by a large mass transport deposit; Dennielou et al., 2019) or open-ocean oceanographic reorganizations (e.g., bottom-current reinforcement and the complete winnowing of the turbidite flows; Shanmugan and Moiola, 1982) are rejected, considering they cannot explain both the cessation of the turbidite activityin the Zambezi Fan and the increase in the terrigenous flux in the Intermediate Basin. The southward rerouting of the 
Zambezi terrigenous flux to the Intermediate Basin at $356 \pm 42$ ka could, however, be explained by (1) a rerouting of Zambezi sediments on the continental shelf under changing coastal oceanographic conditions; (2) a significant change in the location of the Zambezi mouth through time or (3) a combination of the two.

Nowadays, and since the flooding of the continental shelf at ca. $11 \mathrm{ka}$ (van der Lubbe et al., 2014), the Zambezi sediments are transported northwards along the Mozambique coast by large-scale cyclonic eddies. To the North, where the shelf is narrow, they finally reach the clnp. close to the Zambezi Valley. The study of shallow cores al ong the Mozambican margin allows؟ un' $z$ et al. (2011) and van der Lubbe et al. (2014) to demonstrate that this pattern was significantlı $a_{1}$ ' ferent before this time, with lowstand (glacial) conditions favoring the direct transport of the $Z_{r} \mathrm{~nL}_{\mathrm{L}}$ ?zi sediments towards the Intermediate Basin. Hence, one could assume that the 'post-floor'ir, 0 ' highstand (interglacial) pattern for sedime nt dispersion on the Zambezi shelf dominated b $\left.f \mathrm{O}^{r}\right\lrcorner 356 \pm 42 \mathrm{ka}$, with a perennial feeding of the Zambezi Valley and distal fan, while the lowstand pa ${ }^{+}$ern dominated thereafter. This could have been forced by the complex interactions between soriment inputs, delta progradation/retrogradation and oceanographic conditions, i.e., $c_{1}$. गnges in the equilibrium response of the shelf system at long time scale. However, the northward `ar sport of the Zambezi sediments to the Zambezi Valley (i.e. , highstand pattern; Schulz et al., $\iota^{1} 1$; van der Lubbe et al., 2014) does not seem to have an impact on the sedimentation in the Zambezi Valley and the Zambezi Fan, neither today (i.e., Holocene) or during previous interglacials (i.e., MIS 5, 7, 9, 11, 13, 15 and 17 in this study). This is shown by our reconstructions of the turbidite frequency in the Zambezi Fan that does not show any corre lation with sea-level changes (Fig. 18), and of the terrigenous flux at site MOZ4-CSF20 (Fig. 17). Indeed, the latter reveals that peaks in terrigenous flux over the last 150 kyr do not coincide with the highstand conditions (i.e., peak insolation maxima/minima in the northern/southern hemisphere, respectively) but with the maxima in local summer insolation ca. $11 \mathrm{kyr}$ after (Fig. 17). Thus, the monsoon-related precipitation is 
invoked as the main forcing for riverine inputs (but not for the triggering of turbidity currents, at least at the studied sites) in the Mozambique Channel. If such, the climate evolution in Southern East Africa from a predominantly arid environment to generally wetter conditions over the last $1.3 \mathrm{Myr}$ (Lyons et al., 2015; Johnson et al., 2016) could explain the increase of terrigenous inputs to the Intermediary Basin at $356 \pm 42 \mathrm{ka}$. However, it cannot, alone, explain the attendant cessation of the feeding of the upper Zambezi Valley. Based on the above, we speculate that a southward migration of the Zambezi delta is needed to force the depcenter to shift northward, from the distal Zamb ㄱi Fan to the Intermediate Basin ca. $356 \pm 42$ ka.

The expected migration of the Zambezi mouth at ca. $35 \hbar \pm 12 \mathrm{ka}$ (or at least the exceeding of a latitudinal threshold if the migration was gradual) requ:re that the Zambezi delta was in a more northern position before this date. Considering the $e_{8}$ or 1 geological background, this implies that the lower Zambezi was running along the souti, ?rr part of the Mozambique Belt, with a delta located ca. 100-150 km north of its current position, virectly in front of the Upper Zambezi Valley. The current course of the Upper Zambezi Valley : ${ }^{\prime}{ }^{2}{ }^{{ }^{+}}$ed in the middle Miocene (Droz \& Mougenot, 1987), could indicate that such a northern posi، nn oi the Zambezi delta was dominant over the last 10-15 Myr, even if multiple migrations of the $\mathrm{de} \cdot \mathrm{z}$ c, lould have occurred through time. The latter is likely supported by our data from the Zambe. i ran, and the alternating deposition of terrigenous-dominated muds (i.e., "on" mode of the Zambezi Fan) and biogenic-dominated muds (i.e., "off" mode of the Zambezi Fan) at site MOZ2-KSF15 over the last 720 kyr. In details, this sedimentary record could suggest that the disconnection of the Zambezi delta from the Upper Valley known from ca. $356 \pm 42$ ka was also effective between ca. $644 \pm 3$ ka (cf. MOZ2-KSF15) and ca. $550 \pm 20$ ka (cf. MOZ4-CS25) (Figs. 18 and 19). In other words, we assume a northern position of the Zambezi delta before $644 \pm 3 \mathrm{ka}$ (and until $720 \mathrm{ka}$ at least) and between ca. $550 \pm 20 \mathrm{ka}$ (cf. MOZ4-CS25) and ca. $356 \pm 42 \mathrm{ka}$ (cf. MOZ2-KS05) (Fig. 19B), and a 
southern position in between (i.e., from $644 \pm 3$ ka - MOZ2-KSF15- to $550 \pm 20$ ka - MOZ4-CS25-) and afterca. $356 \pm 42 \mathrm{ka}$ (cf. MOZ2-KSO5) (Fig. 19B).

The forcing for the delta migrations may stem from complex origins, in which both autocyclic and allocyclic controls may play a role. Differential subsidence along the Zambezi margin could re present a significant autocyclic control on the delta evolution, as previously shown for the Rhine (Cohen, 2003), Nile (Stanley \& Warne, 1993) or Yangtze (Chen \& Stanley, 1995) rivers. The complex crustal structure of the study area, with a 23-km thick Beira High surrounded by a 7-km thirk c.' 'st under the Lower Zambezi and continental shelf, and the Intermediate Basin (Mueller et dı., zu16), could force a spatially and temporally non-linear rates of differential subsidence of the mar ${ }^{-i n}$. This is corroborated by the complex evolution of the sedimentation and margin development off $t_{1}$. Z Zambezi River throughout the Cenozoic (Walford et al., 2005; Ponte et al., 2018). At this ti. e 'cale, the tectonic history of SE Africa (e.g., deformation of the East African Rift System; ( vor Jwicz, 2005) and the attendant macroevolution of the Zambezi drainage network (Nugent, 1990; Moore \& Larkin, 2001; Moore et al., 2012) have also had a profound effect on the delta evolution ( $\mathrm{W}$ ils ord et al., 2005; Ponte et al., 2018). Thus, one could expect that the drainage evolution obser ، ad in the Zambezi catchment throughout the Pleistocene (disruption reconnection of the Upper and $1^{1}{ }^{1 \mathrm{i} d}$.Zambezi as a prominent example), although not precisely dated (i.e., Early to Mid-Pleistocent, Viuure et al., 2012; Mid- to Late Pleistocene, Moore \& Larkin, 2001), could force the delta migrations and the depocenter changes. To test this assumption, we tracked the sources of the marine sediments found in the Zambezi Fan and in the Intermediate Basin by using neodymium isotopic ratios that is a powerful tracer for geographical provenance (Goldstein and Jacobsen, 1988; Bayon et al., 2015). Interestingly, our results show remarkable homogeneity ( $\varepsilon N d$ of $-14.4 \pm 1.8$ ) over the last $720 \mathrm{kyr}$, both in the yellowish beige and dark grey sediments (Fig. 20A). Considering the high variability in $\varepsilon N d$ of the potential source areas in SE Africa (van der Lubbe et al., 2016; Roddaz et al., 2020), this suggests that the main forcing factor for the observed depocenter changes is certainly not 
related to the evolution of the Zambezi catchment, or that large-scale Pleistocene changes in the Zambezi catchment (Moore \& Larkin, 2001; Moore et al., 2012) pre-date 720 ka.

At this stage, it is not possible to constrain the precise forcing for the depocenter changes observed in the offshore part of the Zambezi routing system. The acquisition of high-resolution seismic data on the continental shelf, and the recognition of paleo-channels on the Zambezi continental margin could help in deciphering the complex evolution of the sedimentation and the source-to-sink dynamics in the Mozambique Channel.

\section{Conclusion}

Deep-sea sediment cores from the Mozambique Chanr =-' allow to investigate the temporal distribution and depositional patterns of terrigenous sedim $n t_{1}$, the Zambezi turbidite system over the last 720 kyr, and to identify the forcing mechanisms controlı, $\tau$ the sediment inputs and their dispersal through time.

Our study reveal low sediment inputs ar.d ar e turbiditic deposits in the Zambezi turbidite system, and the deep (>2,500 m) Mozambique Zha nnelin general, over the studied time interval. The occurrence of turbiditic deposits in the cores suge sts that there is no genetic link between the temporal distribution, and hence triggering, 01 ' $M r$ 'id' es in the MozambiqueChannel and evolving sea-level conditions over the studied period. Accoruing to the terrigenous flux reconstructed at high-resolution over the last 150 kyr in the upper part of the Zambezi depositional system, monsoon-related precipitation appears as the main forcing for riverine inputs in the Zambezi system. Yet, turbiditic deposits do not match the timing of increased riverine inputs. Thus, the transformation of failed sediment is proposed to be the main initiation process for turbidity currents. Finally, our results highlight regional-scale changes in sedimentary facies through time, interpreted as successive depocenter shifts within the Zambezi depositional system (and an on-off evolution of the distal Zambezi Fan) possibly related to significant 
changes in the location of the Zambezi delta through time. Our data suggest a northern location (compared to its modern location) of the Zambezi delta from $\geq 720$ to $644 \pm 3$ ka and from $550 \pm 20$ to $356 \pm 42 \mathrm{ka}$, associated with the delivery of detrital material toward the distal Zambezi Fan (in an "on" mode). The Zambezi delta could have migrated to a more southern location from $644 \pm 3$ to $550 \pm 20 \mathrm{ka}$, and after $356 \pm 42 \mathrm{ka}$ (until today), causing a cessation of the feeding of the upper Zambezi Valley ("off" mode of the Zambezi Fan) and a rerouting of the Zambezi terrigenous flux to the Intermediate Basin. The precise forcing for the delta migration is still not clear and would re, , ire further investigation.

This study highlights how complexand site-specific the study of s' cri great turbidite system is. It brings forward the great complexity of the depositional record in both L - mporal and spatial relationships of the Zambezi turbidite system, whose terrigenous inputs are 50 , trolled by climate and whose sediment distribution is the result of a complex and delicate $k$ al $l_{\text {I }}$ f between sediment transport/sedimentation

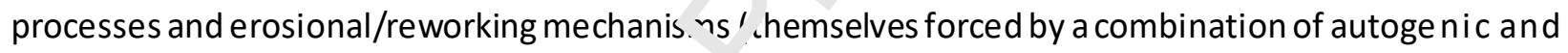
allogenicfactors).

\section{Acknowledgments}

The PhD thesis of Ruth - $^{-i} e_{1} \sim n$, and Master thesis of Elisabeth Jorissen were co-funded by TOTAL and IFREMER as part of the rAMELA (Passive Margin Exploration Laboratories) scientific project. The PAMELA project is a scientific project led by Ifremer and TOTAL in collaboration with Université de Bretagne Occidentale, Université Rennes 1, Université Pierre and Marie Curie, CNRS and IFP-EN.

We thank the Captains and crew members of the 2014 and 2015 data acquisition during cruises PAMELA-MOZ1 and PAMELA-MOZ2 onboard the R/V L'Atalante and PAMELA-MOZ4 onboard of R/V Pourquoipas? and the technicians from Genavir that ensured acquisitions of the geophysical data. The authors sincerely thank the Ifremer technicians (Angélique Roubi and Mickael Rovere) for their support 


\section{Journal Pre-proof}

in the core analysis laboratory and especially Jérémie Gouriou who carried out the TOC analyses on sediment cores. Bernard Dennielou and Nathalie Babonneau are thanked for their preliminary work on some of the sediment cores used in this study. The authors are particularly grateful to Maryline Moulin (Ifremer) for her helpful advice. The authors are also grateful to Jacob A. Covault and David Hodgson for their critical reading and constructive discussions at a preliminary stage of this work. We greatly acknowledge the reviews from the Editor in Chief Vittorio Maselli, from Dr. Marco Fonnesu and from Dr. Andy Green who significantly helped improving the paper. 


\section{References}

Auffret, G., Zaragosi, S., Dennielou, B., Cortijo, E., Van Rooij, D., Grousset, F., Pujol, C., Eynaud, F. and Siegert, M. (2002) Terrigenous fluxes at the Celtic margin during the last glacial cycle. Marine Geology, 188, 79-108. https://doi.org/10.1016/S0025-3227(02)00276-1

Barker, P., Telford, R., Gasse, F. and Thevenon, F. (2002) Late Pleistocene and Holocene palaeohydrology of Lake Rukwa, Tanzania, inferred from diatom analysis. Palaeogeography, Palaeoclimatology, Palaeoecology, 187, 295-305. https://doi.org/1し 1016/S0031-0182(02)00482-0

Bayon, G., Barrat, J.A., Etoubleau, J., Benoit, M., Bollinger, C. and Ré illo I, S. (2009) Determination of rare earth elements, Sc, Y, Zr, Ba, Hf and Th in geological san IPI-_- „y ICP-MS afterTm addition and alkaline fusion. Geostandards and Geoanalytical Researı ? 33 51-62.

https://doi.org/10.1111/j.1751-908X.2008.00880.x

Bayon, G., Dennielou, B., Etoubleau, J., Ponze jeI 1, E., Toucanne, S. and Bermell, S. (2012) Intensifying weathering and land use in Iron r.ge Central Africa. Science, 335, 1219-1222. https://doi.org/10.1126/science.121 ४4`ル

Bayon, G., German, C., Boella, R., N. 'ton, J., Taylor, R. and Nesbitt, R. (2002) An improved method for extracting marine sediment tr stions and its application to $\mathrm{Sr}$ and $\mathrm{Nd}$ isotopic analysis. Chemical Geology, 187, 179-1า9. 'ttp ://doi.org/10.1016/S0009-2541(01)00416-8

Bayon, G., Toucanne, S., S'_.'Jnieczny, C., André, L., Bermell, S., Cheron, S., Dennielou, B., Etoubleau, J., Freslon, N., Gauchery, T., Germain, Y., Jorry, S.J., Ménot, G., Monin, L., Ponzevera, E., Rouget, M. L., Tachikawa, K. and Barrat, J.A. (2015) Rare earth elements and neodymium isotopes in world river sediments revisited. Geochimica et Cosmochimica Acta, 170, 17-38. https://doi.org/10.1016/j.gca.2015.08.001 
Beuning, K.R., Talbot, M.R. and Kelts, K. (1997) A revised 30,000-year paleoclimatic and paleohydrologic history of Lake Albert, East Africa. Palaeogeography, Palaeoclimatology, Palaeoecology, 136, 259279. https://doi.org/10.1016/S0031-0182(97)00034-5

Bonneau, L., Jorry, S.J., Toucanne, S., Silva Jacinto, R. and Emmanuel, L. (2014) Millennial-Scale Response of a Western Mediterranean River to Late Quaternary Climate Changes: A Vie w from the Deep Sea. The Journalof Geology, 122, 687-703. https://doi.org/10.1086/677844

Bonnefille, R. (1983) Evidence for a cooler and drier climate in the Ethic, ian uplands towards 2.5 Myr ago. Nature, 303, 487. https://doi.org/10.1038/303487a0

Bouma, A. (2001) Fine-grained submarine fans as possible re :or '- .s of long-and short-term climatic changes. Global and Planetary Change, 28, 85-91. https.,'/do .org/10.1016/S0921-8181(00)00066-7

Bourget, J., Zaragosi, S., Garlan, T., Gabelotaud, I., G uy smard, P., Dennielou, B., Ellouz-Zimmermann, N. and Schneider, J. (2008) Discovery of , gi nt Ieep-sea valley in the Indian Ocean, off eastern Africa: The Tanzania hannel. Marine Geology, 255, 179-185. https://doi.org/10.1016/j.margeo.2C )\& し? 002

Bourget, J., Zaragosi, S., Ellouz-Z:n. nermann, S., Ducassou, E., Prins, M., Garlan, T., Lanfumey, V., Schneider, J.-L., Rouillard P. 'nd Giraudeau, J. (2010) Highstand vs. lowstand turbidite system growth in the Mak. ^n 'ctiv 2 margin: Imprints of high-frequency external controls on sediment delivery mechanisi. - to deep water systems. Marine Geology, 274, 187-208. https://doi.org/10.1016/j.margeo.2010.04.005

Bourget, J., Zaragosi, S., Ellouz-Zimmermann, N., Mouchot, N., Garlan, T., Schneider, J., Lanfumey, V. and Lallemant, S. (2011) Turbidite system architecture and sedimentary processes along topographically complex slopes: the Makran convergent margin. Sedimentology, 58, 376-406. https://doi.org/10.1111/j.1365-3091.2010.01168.x 
Bourillet, J.-F., Damy, G., Dussud, L., Sultan, N., Woerther, P. and Migeon, S. (2007) Behaviour of a piston corer from accelerometers and new insights on quality of the recovery. In: Proceedings of the Sixth International Offshore Site Investigation and Geotechnics Conference: Confronting New Challenges and Sharing Knowledge, 11-13 September, 2007, London, UK.

Bouvier, A., Vervoort, J.D. and Patchett, P.J. (2008) The Lu-Hf and Sm-Nd isotopic composition of CHUR: constraints from unequilibrated chondrites and implications for the bulk composition of terrestrial planets. Earth and Planetary Science Letters, 273 (1-2), 48- - 7. https://doi.org/10.1016/j.epsl.2008.06.010

Boyd, R., Ruming, K., Goodwin, I., Sandstrom, M. and Schrödel-Ac'-..1S, C. (2008) Highstand transport of coastal sand to the deep ocean: A case study from Fra orls and, southeast Australia. Geology, 36, 15. https://doi.org/10.1130/G24211A.1

Breitzke, M., Wiles, E., Krocker, R., Watkey', N K. .nd Jokat, W. (2017) Seafloor morphology in the Mozambique Channel: evidence for !nng-terı.i persistent bottom-current flow and deep-reaching eddy activity. Marine Geophysical R 'sf G. -h, 38, 241-269. https://doi.org/10.1007/s11001-017-93227

Brown, E., Johnson, T., Scholz C., ' ' hhen, A. and King, J. (2007) Abrupt change in tropical African climate linked to the bipolai -e saw Jver the past 55,000 years. Geophysical Research Letters, 34 (20). https://doi.org/10.10こ_; 2007GL031240

Caley, T., Extier, T., Collins, J.A., Schefuß, E., Dupont, L., Malaizé, B., Rossignol, L., Souron, A., McClymont, E.L., Jimenez-Espejo, F.J., García-Comas, C., Eynaud, F., Martinez, P., Roche, D.M., Jorry, S.J., Charlier, K., Wary, M., Gourves, P.-Y., Billy, I. and Giraudeau, J. (2018) A two-million-yearlong hydroclimatic context for hominin evolution in southeastern Africa. Nature, 560, 76-79. https://doi.org/10.1038/s41586-018-0309-6 
Castañeda, I.S., Caley, T., Dupont, L., Kim, J.-H., Malaizé, B. and Schouten, S. (2016) Middle to Late Pleistocene vegetation and climate change in subtropical southern East Africa. Earth and Planetary Science Letters, 450, 306-316. https://doi.org/10.1016/j.epsl.2016.06.049

Castelino, J.A., Reichert, C. and Jokat, W. (2017) Response of Cenozoic turbidite system to tectonic activity and sealevel change off the Zambezi Delta. Mar Geophys Res., 38, 209-226. https://doi.org/10.1007/s11001-017-9305-8

Cattaneo, A., Riboulot, V., Jouet, G., Lempreur, C., Scalabrin, C., I’ arsett, T., Le Roy, P., Droz, L., Deville, E. and Cauquil, E. (2017) Submarine landslides im, act on the morphology of the Mozambique continental margin. In IMS 2017-Internationa' $\iota_{\iota^{*}}{ }^{*}$..g of Sedimentology, pp. 161.

Cerling, T.E. (1992) Development of grasslands and savannc - in I ast Africa during the Neogene. Palaeogeography, Palaeoclimatology, Palaeoecolc yy @7, 241-247. https://doi.org/10.1016/00310182(92)90211-M

Cerling, T.E., Harris, J.M., MacFadden, B.' Leake, , M.G., Quade, J., Eisenmann, V. and Ehleringer, J.R. (1997) Global vegetation change thr( $u$, r, the Miocene/Pliocene boundary. Nature, 389, 153-158. https://doi.org/10.1038/38229

Chen, Z. and Stanley, D. J. (1995) \& 'aternary subsidence and river channel migration in the Yangtze Delta Plain, Eastern -hiı э.Jc urnalof Coastal Research, 11 (3), 927-945.

Clark, J.D. and Pickering, : . . (1996). Architectural elements and growth patterns of submarine channels: application to hydrocarbon exploration. AAPG bulletin, 80, 194-220.

Clift, P.D., Hodges, K.V., Heslop, D., Hannigan, R., Van Long, H., Calves, G. (2008). Correlation of Himalayan exhumation rates and Asian monsoon intensity. Nature geoscience, 1(12), 875-880. https://doi.org/10.1038/ngeo351

Cohen, K.M. (2003) Differential subsidence within a coastal prism: late-Glacial-Holocene tectonics in The Rhine-Meuse delta, the Netherlands (Doctoral dissertation). 
Cotterill, F.P.D. (2006) The evolutionary history and taxonomy of the Kobus leche species complex of south-central Africa in the context of Palaeo-drainage dynamics. PhD Thesis, University of Stellenbosch.

Counts, J.W., Jorry, S.J., Leroux, E., Miramontes, E. and Jouet, G. (2018). Sedimentation adjacent to atolls and volcano-cored carbonate platforms in the Mozambique Channel (SW Indian Ocean). Marine Geology, 404, 41-59. https://doi.org/10.1016/j.margeo.2018.07.003

Courgeon, S., Jorry, S.J, Camoin, G.F., BouDagher-Fadel, M.K., Joue., G., Révillon, S., Bachèlery, P., Pelleter, E., Borgomano, J. and Poli, E. (2016) Growth and demi. o o Cenozoic isolated carbonate platforms: New insights from the Mozambique Channel jea.” unts (SW Indian Ocean). Marine Geology, 380, 90-105. https://doi.org/10.1016/j.margeı 201 j.07.006

Covault, J.A. and Graham, S.A. (2010) Submarine fans at d" sea-level stands: Tectono-morphologic and climatic controls on terrigenous sedim nt de very to the deep sea. Geology, 38, 939-942. https://doi.org/10.1130/G31081.1

Covault, J.A., Romans, B.W., Fildani, A, McGann, M., Graham, S.A. (2010). Rapid climatic signal propagation from source to sirk in a southern California sediment-routing system. The Journal of Geology, 118, 247-259.

deMenocal, P.B. (2004; Afr can limate change and faunal evolution during the Pliocene-Pleistocene. Earth and Planetary Sc:-. Ice Letters, 220, 3-24. https://doi.org/10.1016/S0012-821X(04)00003-2

Dennielou, B., Jégou, I., Droz, L., Jouet, G., Cattaneo, A., Berné, S., Aslanian, D., Loubrieu, B., Rabineau, M. and Bermell, S. (2019) Major modification of sediment routing by a large Mass Transport Deposit in the Gulf of Lions (Western Mediterranean). Marine Geology, 411, 1-20. https://doi.org/10.1016/j.margeo.2019.01.011

Deville, E., Marsset, T., Courgeon, S., Jatiault, R., Ponte, J.P., Thereau, E., Jouet, G., Jorry, S.J. and Droz, L. (2018) Active fault system across the oceanic lithosphere of the Mozambique Channel:Implications 
for the Nubia-Somalia southern plate boundary. Earth and Planetary Science Letters, 502, 210-220. https://doi.org/10.1016/j.epsl.2018.08.052

De Ruijter, W.P.M., Ridderinkhof, H., Lutjeharms, J.R.E., Schouten, M.W. and Veth, C. (2002) Observations of the flow in the Mozambique Channel. Geophysical Research Letters, 29, 140-1-1403. https://doi.org/10.1029/2001GL013714

Donohue, K.A. and Toole, J.M. (2003) A near-synoptic survey of the Southwest Indian Ocean. Deep Sea Research Part II: Topical Studies in Oceanography, 50, 1893-1931 nttps://doi.org/10.1016/S09670645(03)00039-0

Droz, L. and Mougenot, D. (1987) Mozambique upper fan: ori şir =f depositional units. AAPG Bulletin, 71, 1355-1365.

Droz, L., Marsset, T., Ondreas, H., Lopez, M., Savoye B and Spy-Anderson, F. L. (2003) Architecture of an active mud-rich turbidite system: The Z; re 'an ' 'ongo-Angola margin southeast Atlantic) Results from ZaïAngo 1 and 2 cruises. AAPG bi/lletin, 8, 1145-1168. https://doi.org/10.1306/03070300013

Ducassou, E., Migeon, S., Mulder, T., n lu' a . A., Capotondi, L., Bernasconi, S.M. and Mascle, J. (2009) Evolution of the Nile deep-ser L.rbiaite system during the Late Quaternary: influence of climate change on fan sedimentatic Sedimentology, 56, 2061-2090. https://doi.org/10.1111/j.13653091.2009.01070.x

Fierens, R., Droz L., Tou_-.ne, S., Jorry, S.J., Raisson, F., Jouet G., Babonneau, N. and Landurain, S. (2019) Submarine geomorphology of the Zambezi turbidite system and its tributaries from new bathymetric data. Marine Geology, 334, 1-28. https://doi.org/10.1016/j.geomorph.2019.02.033

Flemming, B.W. and Kudrass, H.-R. (2018) Large dunes on the outer shelf off the Zambezi Delta, Mozambique: evidence for the existence of a Mozambique Current. Geo-Marine Letters, 38, 95-106. https://doi.org/10.1007/s00367-017-0515-5 
Fonnesu, M., Palermo, D., Galbiati, M., Marchesini, M., Bonamini, E. and Bendias, D. (2020) A new world-class deep-water play-type, deposited by the syndepositional interaction of turbidity flows and bottom currents: The giant Eocene Coral Field in northern Mozambique. Marine and Petroleum Geology, 111, 179-201. https://doi.org/10.1016/j.marpetgeo.2019.07.047

Fontijn, K., Williamson, D., Mbede, E. and Ernst, G.G.J. (2012) The Rungwe Volcanic Province, Tanzania - A volcanological review. J. African Earth Sci. , 63, 12-31.

https://doi.org/10.1016/j.jafrearsci.2011.11.005

Garcin, Y., Vincens, A., Williamson, D., Guiot, J. and Buchet, G. (2006, Wf t phases in tropical southern

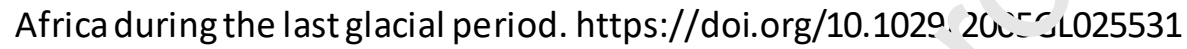

Gardner, W.D., Tucholke, B.E., Richardson, M.J. and Bisi 've, P.E. (2017) Benthic storms, nepheloid layers, and linkage with upper ocean dynamics in t' ie ' $\mathrm{s}$ ?stern North Atlantic. Marine Geology, 385, 304-327. https://doi.org/10.1016/j.marge',.2૮ 16. ?.012

GEBCO (2014) GEBCO_2014 Grid. British Oc anographic Data Centre (BODC). Available at: http://www.gebco.net/data_and_k rc

Goldstein, S.J. and Jacobsen, S.: (1)88) Nd and Sr isotopic systematics of river water suspended material: implications for , nu, tal evolution. Earth and Planetary Science Letters, 87, 249-265.

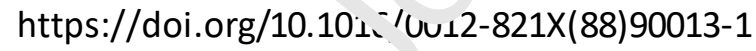

Goodbred Jr, S.L. and Kuehl, S.A. (2000) Enormous Ganges-Brahmaputra sediment discharge during strengthened early Holocene monsoon. Geology, 28 (12), 1083-1086. https://doi.org/10.1130/00917613(2000)28<1083:EGSDDS>2.0.CO;2

Govin, A., Holzwarth, U., Heslop, D., Ford Keeling, L., Zabel, M., Mulitza, S., Collins, J.A. and Chiessi, C.M. (2012) Distribution of major elements in Atlantic surface sediments (36 N-49 S): Imprint of terrigenous input and continental weathering. Geochemistry, Geophysics, Geosystems, 13, 15252027. https://doi.org/10.1029/2011GC003785 
Grant, K., Rohling, E., Ramsey, C.B., Cheng, H., Edwards, R., Florindo, F., Heslop, D., Marra, F., Roberts, A. and Tamisiea, M.E. (2014) Sea-level variability over fiveglacial cycles. Nature communicati ons, 5, 5076. https://doi.org/10.1038/ncomms6076

Green, A. (2011a) The late Cretaceous to Holocene sequence stratigraphy of a sheared passive upper continental margin, northern KwaZulu-Natal, South Africa. Marine Geology, 289, 17-28. https://doi.org/10.1016/j.margeo.2011.09.001

Green, A. (2011b) Submarine canyons associated with alternating sedir, snt starvation and shelf-edge wedge development: Northern KwaZulu-Natal continental mar ${ }_{\varepsilon}^{i n, ~ ' o u t h ~ A f r i c a . ~ M a r i n e ~ G e o l o g y, ~}$ 284, 114-126. https://doi.org/10.1016/j.margeo.2011.03.01 L

Halo, I., Backeberg, B., Penven, P., Ansorge, I., h.'ass n, C. and Ullgren, J.E. (2014) Eddy properties in the Mozambique Channel: A comp $\wedge^{i}, c$ ᄀ between observations and two numerical ocean circulation models. Deep Sea Rese ،rch Par. II: Topical Studies in Oceanography, 100, 38-53. https://doi.org/10.1016/j.dsr2.2013.1C 015

Hesse, R. and Khodabakhsh, S. (1998) Jr pr witional facies of late Pleistocene Heinrich events in the Labrador Sea. Gecloy:. 26, 103-106. https://doi.org/10.1130/00917613(1998)026<0103:DFOL.'H>2.2.CO;2

Hicks, N. and Green, ^. $\left(\mathrm{?}^{\mathrm{D}} \mathrm{1}^{-}\right)$A Mid-Miocene erosional unconformity from the Durban Basin, SE African margin: A corıinination of global eustatic sea level change, epeirogenic uplift, and ocean current initiation. Marine and Petroleum Geology, 86, 798-811. https://doi.org/10.1016/j.marpetgeo.2017.06.037

Hinderer, M. (2012) From gullies to mountain belts: A review of sediment budgets at various scales. Sedimentary Geology, 280, 21-59. https://doi.org/10.1016/j.sedgeo.2012.03.009

Howard, W.R. (1997) Palaeoclimatology: A warm future in the past. Nature, 388, 418-419. https://doi.org/10.1038/41201 
Howell, J.A., Martinius, A.W. and Good, T.R. (2014) The application of outcrop anal ogues in ge ol ogical modelling: a review, present status and future outlook. Geological Society, London, Special Publications, 387, 1-25. https://doi.org/10.1144/SP387.12

Johnson, T.C., Brown, E.T., McManus, J., Barry, S., Barker, P. and Gasse, F. (2002) A high-resolution paleoclimate record spanning the past 25,000 years in southern East Africa. Science, 296, 113-132. https://doi.org/10.1126/science.1070057

Johnson, T.C., Werne, J.P., Brown, E.T., Abbott, A., Berke, M., Steinm. ‘. B.A., Halbur, J., Contreras, S., Grosshuesch, S., Deino, A., Scholz, C.A., Lyons, R.P., Schoute`S and Damsté, J.S.S. (2016) A progressively wetter climate in southern East Africa over thc. pa_ +1.3 million years. Nature, 537, 220. https://doi.org/10.1038/nature19065

Jorry, S.J., Camoin, G.F., Jouet, G., Le Roy, P., Vella, C. Courgeon, S., Prat, S., Fontanier, C., Paumard, V. and Boulle, J. (2016) Modern sediments ani Plt 'stocene reefs from isolated carbonate platforms (Iles Eparses, SW Indian Ocean) A proliminary study. Acta Oecologica, 72, 129-143. https://doi.org/10.1016/j.actao.2015 1א...17

Jorry, S.J., Jegou, I., Emmanuel, L., S.. ‘a Jacinto, R. and Savoye, B. (2011). Turbiditiclevee deposition in response to climate changos: 1 'e Var Sedimentary Ridge (Ligurian Sea). Marine Geology, 279 (1-4), 148-161. https://dc: or $/ 10$. .016/j.margeo.2010.10.021

Jouet, G. and Des:".e, E. (2015) PAMELA-MOZO4 cruise, RV Pourquoi Pas ?, http://dx.doi.org/10.17600/15000700

Jung, S.J.A., Davies, G.R., Ganssen, G.M., and Kroon, D. (2004). Stepwise Holocene aridification in NE Africa deduced from dust-borne radiogenic isotope records. Earth and Planetary Science Letters, 221(1-4), 27-37. https://doi.org/10.1016/S0012-821X(04)00095-0 
Just, J., Schefuß, E., Kuhlmann, H., Stuut, J.-B.W. and Pätzold, J. (2014) Climate induced sub-basin source-area shifts of Zambezi River sediments over the past 17ka. Palaeogeography, Palaeoclimatology, Palaeoecology, 410, 190-199. https://doi.org/10.1016/j.palaeo.2014.05.045

Kolla, V., Eittreim, S., Sullivan, L., Kostecki, J.A. and Burckle, L.H. (1980a) Current-controlled, abyssal microtopography and sedimentation in Mozambique Basin, Southwest Indian Ocean. Marine Geology, 34, 171-206. https://doi.org/10.1016/0025-3227(80)90071-7

Kolla, V., Kostecki, J.A., Henderson, L. and Hess, L. (1980b) Morphology ind Quaternary sedimentation of the Mozambique Fan and environs, southwestern Indian O Jan Sedimentology, 27, 357-378. https://doi.org/10.1111/j.1365-3091.1980.tb01188.x

Kolla, V. and Perlmutter, M. (1993) Timing of turbidite S, dim যntation on the Mississippi Fan. AAPG Bulletin, 77, 1129-1141.

Kristen, I., Wilkes, H., Vieth, A., Zink, K.-G., Pl'ssı n, L Thorpe, J., Partridge, T. and Oberhänsli, H. (2010) Biomarker and stable carbon isctope arılyses of sedimentary organic matter from Lake Tswaing: evidence for deglacial wetr es', a d early Holocene drought from South Africa. Journal of Paleolimnology, 44, 143-160. h+th - //aoi.org/10.1007/s10933-009-9393-9

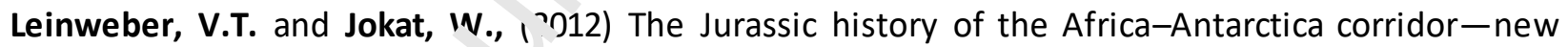
constraints from mấ ${ }_{i}$ ne ic d: ta on the conjugate continental margins. Tectonophysics, 530, 87-101. https://doi.org/10.10:', j.tecto.2011.11.008

Lisiecki, L.E. and Raymo, M.E. (2005) A Pliocene-Pleistocene stack of 57 globally distributed benthic $\delta^{18} \mathrm{O}$ records. Paleoceanography, 20, PA1003, http://doi.org/10.1029/2004PA001071

Liu, X., Rendle-Bühring, R. and Henrich, R. (2016) Climate and sea-level controls on turbidity current activity on the Tanzanian upper slope during the last deglaciation and the Holocene. Quaternary Science Reviews, 133, 15-27. https://doi.org/10.1016/j.quascirev.2015.12.002 
Lyons, R.P., Scholz, C.A., Cohen, A.S., King, J.W., Brown, E.T., Ivory, S.J., Johnson, T.C., Deino, A.L., Reinthal, P.N., McGlue, M.M. and Blome, M.W. (2015) Continuous 1.3-million-year record of East African hydroclimate, and implications for patterns of evolution and biodiversity. Proceedings of the National Academy of Sciences, 112, 15568-15573. https://doi.org/10.1073/pnas.1512864112

Maghraoui, M.E., Joron, J., Etoubleau, J., Cambon, P. and Treuil, M. (1999) Determination of forty four major and trace elements in GPMA magmatic rock reference materials using X-ray Fluorescence Spectrometry (XRF) and Instrumental Neutron Activation Analy is (INAA). Geostandards and Geoanalytical Research, 23, 59-68. https://doi.org/10.1111/j.175_ 908 X.1999.tb00559.x

Mahanjane, E.S. (2014) The Davie Fracture Zone and adjace it ; - Ins in the offshore Mozambique Margin - A new insights for the hydrocarbon potential. ; 'ari e and Petroleum Geology, 57, 561-571. https://doi.org/10.1016/j.marpetgeo.2014.06.015

Mayall, M., Jones, E. and Casey, M. (2006) Iu bic “e channel reservoirs-Key elements in facies prediction and effective develorment. Marine and Petroleum Geology, 23, 821-841. https://doi.org/10.1016/j.marpetgec , $2^{\prime} \varkappa=08.001$

McCave, I., Kiefer, T., Thornalley, Г. . nd Elderfield, H. (2005). Deep flow in the Madagascar-Mascarene

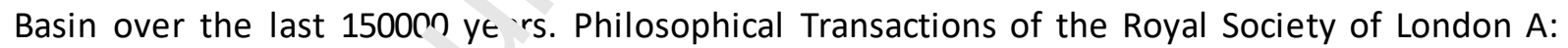

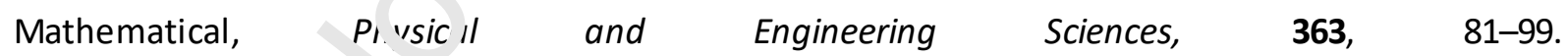
https://doi.org/10.10s?'rsta.2004.1480

Meyer, I., Davies, G.R., and Stuut, J.B.W. (2011). Grain size control on Sr-Nd isotope provenance studies and impact on paleoclimate reconstructions: An example from deep-sea sediments offshore NW Africa. Geochemistry, Geophysics, Geosystems, 12(3). https://doi.org/10.1029/2010GC003355

Micallef, A., Georgiopoulou, A., Green, A. and Maselli, V. (2019) Impact of sea-level fluctuations on the sedimentation patterns of the SE African margin: implications for slope instability. Geological Society, London, Special Publications, SP500-2019-172. https://doi.org/10.1144/SP500-2019-172 
Milliman, J.D. and Farnsworth, K.L. (2011) River discharge to the coastal ocean: a global synthesis. Cambridge University Press.

Miramontes, E., Penven, P., Fierens, R., Droz, L., Toucanne, S., Jorry, S.J., Jouet, G., Pastor, L., Silva, J. R., Gaillot, A., Giraudeau, J. and Raisson F. (2019) The influence of bottom currents on the Zambezi Valley morphology (Mozambique Channel, SW Indian Ocean): In situ current observations and hydrodynamic modelling. Marine Geology, 410, 42-55.

https://doi.org/10.1016/j.margeo.2019.01.002

Moore, A.E. and Cotterill, F.P.D. (2010) Victoria Falls: Mosi oa Tuny -t ie smoke that thunders, In: P. Mignon (Editor), Geomorphological Landscapes. Suritı̈-., Berlin, Germany, 143-153. https://doi.org/10.1007/978-90-481-3055-9_15

Moore, A.E., Cotterill, F.P.D. and Eckardt, F.D. (2012' Tr.e evolution and ages of Makgadikgadi palaeolakes: Consilient evidence from Kalahari arc nas? evolution South-Central Africa. South African Journal of Geology, 115, 385-413. httrc://doi.urg/10.2113/gssajg.115.3.385

Moore, A.E. and Larkin, P.A. (2001) DI jir ia :2 evolution in south-central Africa since the breakup of Gondwana. South African Journ æı 、f Geology, 104, 47-68. https://doi.org/10.2113/104.1.47

Mueller, C.O., Jokat, W. and Sch. `ckenberger, B. (2016) The crustal structure of Beira High, central Mozambique-Com.hin d nvestigation of wide-angle seismic and potential field data. Tectonophysics, 683, 2ొ?-254. https://doi.org/10.1016/j.tecto.2016.06.028

Normark, W.R. and Piper, D.J. (1991) Initiation processes and flow evolution of turbidity currents: implications for the depositional record. SEPMSpec. Pub., 46, 207-230.

Normark, W.R., Posamentier, H. and Mutti, E. (1993) Turbidite systems: state of the art and future directions. Reviews of Geophysics, 31, 91-116. https://doi.org/10.1029/93RG02832 
Nugent, C., (1990) The Zambezi River: tectonism, climatic change and drainage evolution. Palaeogeography, Palaeoclimatology, Palaeoecology, 78, 55-69. https://doi.org/10.1016/00310182(90)90204-K

Olu, K. (2014) PAMELA-MOZ01 cruise, RV L'Atalante, http://dx.doi.org/10.17600/14001000

Partridge, T., deMenocal, P., Lorentz, S., Paiker, M. and Vogel, J. (1997) Orbital forcing of climate over South Africa: a 200,000-year rainfall record from the Pretoria Saltpan. Quaternary Science Reviews, 16, 1125-1133. https://doi.org/10.1016/S0277-3791(97)00005-X

Pettingill, H.S. and Weimer, P. (2002) Worlwide deepwater exploratı ' n a' 'd production: Past, pre sent, and future. The Leading Edge, 21, 371-376. https://doi.org/ (0.15J/1.1471600

Picot, M., Marsset, T., Droz, L., Dennielou, B., Baudin, F., h. rmc so, M., De Rafélis, M., Sionneau, T., Cremer, M. and Laurent, D. (2019) Monsoon contr د ' , r channel avulsions in the Late Quaternary Congo Fan. Quaternary Science Reviews, 25 *, $19-: 71$. https://doi.org/10.1016/j.quascirev.2C18.11.0_3

Piper, D.J. and Normark, W.R. (2009) P O'. ' ' es that initiate turbidity currents and their influence on turbidites: a marine geolog" 'erspective. Journal of Sedimentary Research, 79, 347-362. https://doi.org/10.2110/jsr. 20u` 046

Piper, D., Pirmez, C., Ma. ley P., Long, D., Flood, R., Normark, W. and Showers, W. (1997) Masstransport deposits of '.e Amazon Fan. In: Proceedings ODP Scientific Results (Flood, R.D., Piper, D.J.W., Klaus, A., and Peterson, L.C., eds. ), 155, 109-146.

Piper, D.J., Shaw, J. and Skene, K.I. (2007) Stratigraphic and sedimentological evidence for late Wisconsinan sub-glacial outburst floods to Laurentian Fan. Palaeogeography, Palaeoclimatology, Palaeoecology, 246, 101-119. https://doi.org/10.1016/j.palaeo.2006.10.029

Ponte, J.P., Robin, C., Guillocheau, F., Popescu, S., Suc, J.-P., Dall'Asta, M., Melinte-Dobrinescu, M.C., Bubik, M., Dupont, G. and Gaillot, J. (2018) The Zambezi delta (Mozambique channel, East Africa): 
High resolution dating combining bio-orbital and seismic stratigraphy to determine climate (palaeoprecipitation) and tectonic controls on a passive margin. Marine and Petroleum Geology, 105, 293-312. https://doi.org/10.1016/j.marpetgeo.2018.07.017

Posamentier, H.W. and Kolla, V. (2003) Seismic geomorphology and stratigraphy of depositional elements in deep-water settings. Journal of sedimentary research, 73, 367-388. https://doi.org/10.1306/111302730367

Posamentier, H. and Vail, P. (1988) Eustatic controls on clastic depos ion II-sequence and systems tract models. In: Sea Level Changes-An Integrated Approach (C. ' W W Igus, B. S. Hastings, C. G. St.C. Kendall, H. W. Posamentier, C. A. Rossand , J. C. Van Wage ne, rds.), SEPM Special Publication, 42, pp. 125-154.

Potts, R. (1996) Evolution and climate variability. Scie ICf, ?73, 922-923. https://doi.org/10.1126/science.273.5277'/2L

Prins, M.A. and Postma, G. (2000) Effects of c.imate, sea level, and tectonics unraveled for last deglaciation turbidite records $\iota^{f}$ the Arabian Sea. Geology, 28, 375-378. https://doi.org/10.1130/0091-75^?'2000)28\%3C375:EOCSLA\%3E2.0.CO;2

Prins, M., Postma, G. and Weltje, G.J. (2000) Controls on terrigenous sediment supply to the Arabian Sea during the latc $Q_{1}$ эte nary: the Makran continental slope. Marine Geology, 169, 351-371. https://doi.org/10.10:',j0025-3227(00)00087-6

Quartly, G.D. and Srokosz, M.A. (2004) Eddies in the southern Mozambique Channel. Deep Sea Research Part II: Topical Studies in Oceanography, 51, 69-83. https://doi.org/10.1016/j.dsr2.2003.03.001

Railsback, L.B., Gibbard, P.L., Head, M.J., Voarintsoa, N.R.G. and Toucanne, S. (2015) An optimized scheme of lettered marine isotope substages for the last 1.0 million years, and the 
climatostratigraphic nature of isotope stages and substages. Quaternary Science Reviews, 111, 94106. https://doi.org/10.1016/j.quascirev.2015.01.012

Reimer, P.J., Bard, E., Bayliss, A., Beck, J.W., Blackwell, P.G., Ramsey, C.B., Buck, C.E., Cheng, H., Edwards, R.L. and Friedrich, M. (2013) IntCal13 and Marine13 radiocarbon age calibration curves 050,000 years cal BP. Radiocarbon, 55, 1869-1887. https://doi.org/10.2458/azu_js_rc.55.16947

Remacha, E. and Fernández, L.P. (2003) High-resolution correlation patterns in the turbidite syste ms of the Hecho Group (South-Central Pyrenees, Spain). Marine and I troleum Geology, 20, 711-726. https://doi.org/10.1016/j.marpetgeo.2003.09.003

Richter, T.O., Van der Gaast, S., Koster, B., Vaars, A., Gieles, 2., _- jtigter, H.C., De Haas, H. and van Weering, T.C. (2006) The Avaatech XRF Core Scanner: ach ical description and applications to NE Atlantic sediments. Geological Society, lordan, Special Publications, 267, 39-50. https://doi.org/10.1144/GSL.SP.2006.267.C _.U.

Ridderinkhof, H. and de Ruijter, W.P.M. (200ऽ, Moored current observations in the Mozambique Channel. Deep Sea Research P irt ' Topical Studies in Oceanography, 50, 1933-1955. https://doi.org/10.1016/S0967-7t '5(03)00041-9

Rebesco, M., Hernández-Molina, - J., Van Rooij, D. and Wåhlin, A. (2014) Contourites and associated sediments controll $\epsilon^{`}$ by dee J-water circulation processes: state-of-the-art and future considerations. Marine Geology, 352, _-154. https://doi.org/10.1016/j.margeo.2014.03.011

Robin, C. and Droz, L. (2014) PAMELA-MOZ02 cruise, RV L'Atalante, http://dx.doi.org/10.17600/14001100

Roddaz, M., Nauton-Fourteu, M., Santos, R.V., Dantas, E.L. and Calves, G. (2020) Controls on the provenance of late Eocene to Quaternary Mozambique Channel shales (DSDP 25 Site 242). Marine Geology, 421, 106090, https://doi.org/10.1016/j.margeo.2019.106090 
Romans, B.W., Castelltort, S., Covault, J.A., Fildani, A. and Walsh, J. (2016) Environmental signal propagation in sedimentary systems across timescales. Earth-Science Reviews, 153, 7-29. https://doi.org/10.1016/j.earscirev.2015.07.012

Rothwell, R.G., Hoogakker, B., Thomson, J., Croudace, I.W. and Frenz, M., (2006) Turbidite emplacement on the southern Balearic Abyssal Plain (western Mediterranean Sea) during Marine Isotope Stages 1-3: an application of ITRAX XRF scanning of sediment cores to lithostratigraphic analysis. Geological Society, London, Special ' 'iblications, 267, 79-98. https://doi.org/10.1144/GSL.SP.2006.267.01.06

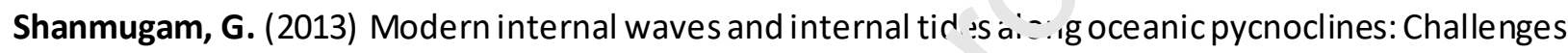
and implications for ancient deep-marine baroclinic sanı sInt :rnal Waves, Internal Tides, and Baroclinic Sands. AAPG bulletin, 97, 799-843. http: :// di.org/10.1306/10171212101

Shanmugam, G. (2018) A global satellite survf yo deı. sity plumes at river mouths and at other environments: Plume configurations, cxternal ఒontrols, and implications for deep-water sedimentation. Petroleum Exploratic $7 \mathrm{r} r$ v Development, 45, 640-661. https://doi-org.scdproxy.univ-brest.fr/10.1016/S19\% 3804(18)30069-7

Shanmugam, G. and Moiola, P. (1ะ??) Eustatic control of turbidites and winnowed turbidites. Geology, 10, 231-235. https:,',dc org '10.1130/0091-7613(1982)10\%3C231:ECOTAW\%3E2.0.CO;2

Shanmugam, G., Moiola, ?. and Damuth, J. (1985) Eustatic control of submarine fan development, in: Submarine Fans and Related Turbidite Systems. Springer, New York, NY., 23-28. https://doi.org/10.1007/978-1-4612-5114-9_5

Shanmugam, G. and Moiola, R.J. (1988) Submarine fans: characteristics, models, classification, and reservoir potential. Earth-Science Reviews, 24, 383-428. https://doi.org/10.1016/0012$8252(88) 90064-5$ 
Schefuß, E., Schouten, S. and Schneider, R.R. (2005) Climatic controls on central African hydrology during the past 20,000 years. Nature, 437, 1003-1006. https://doi.org/10.1038/nature03945

Scholz, C.A., Johnson, T.C., Cohen, A.S., King, J.W., Peck, J.A., Overpeck, J.T., Talbot, M.R., Brown, E.T., Kalindekafe, L. and Amoako, P.Y. (2007) East African megadroughts between 135 and 75 thousand years ago and bearing on early-modern human origins. Proceedings of the National Academy of Sciences, 104, 16416-16421. https://doi.org/10.1073/pnas.0703874104

Schouten, M.W., de Ruijter, W.P., Van Leeuwen, P.J. and Ridderinkhoı ન. (2003) Eddies and variability in the Mozambique Channel. Deep Sea Research Part II: Topical studi ss in Oceanography, 50, 19872003. https://doi.org/10.1016/S0967-0645(03)00042-0

Schulz, H., Lückge, A., Emeis, K.-C. and Mackensen, A. (201. ' Va iability of Holocene to Late Pleistocene Zambezi riverine sedimentation at the upper cor ir $\_n t a l$ slope off Mozambique, $15^{\circ}-21^{\circ} \mathrm{S}$. Marine Geology, 286, 21-34. https://doi.org/10.10 ^6/ ma "geo.2011.05.003

Shipboard Scientific Party (1998) Explancºry not s. In: Wefer, G., Berger, W.H., Richter, C., etal., Proc. ODP, Init. Repts., 175: Col'əgょ Station, TX (Ocean Drilling Program), 27-46. https://doi.org/10.2973/odp.prx. ir.1\%5.102.1998

Simms, MJ. (2000) Preliminarv re, गrt of the succession in Lake Patrick, Zambia. In: The Middle Stone Age in Zambia, Wes, orn Aca 'emic Specialist Press. (Ed. L.S. Barham), pp. 279-282.

Simon, M.H., Ziegler, M., ? ssmans, J., Barker, S., Reason, C.J. and Hall, I.R. (2015) Eastern South African hydroclimate over the past 270,000 years. Scientific reports, 5, 18153. https://doi.org/10.1038/srep18153

Simpson, E.S.W., Schlich, R., Gieskes, J., Girdley, W.A., Leclaire, L., Marshall, V.B., Moore, C., Muller, C., Sigal, J., Valuer, T.L., White and S.M., Zobel, B. (1974) Sites 243 and 244. In: Simpson, E., Schlich, R. (Eds.), Initial Reports of the Deep Sea Drilling Project. 25. U.S. Government Printing Office, Washington, D.C., pp. 743-760. https://doi.org/10.2973/dsdp.proc.25.106.1974. 
Skene, K.I. and Piper, D.J.W. (2003) Late Quaternary stratigraphy of Laurentian Fan: a record of events off the eastern Canadian continental margin during the late deglacial period. Quaternary International, 99, 135-152. https://doi.org/10.1016/S1040-6182(02)00116-7

Soulet, G. (2015) Methods and codes for reservoir-atmosphere 14C age offset calculations. Quaternary Geochronology, 29, 97-103. https://doi.org/10.1016/j.quageo.2015.05.023

Southon, J., Kashgarian, M., Fontugne, M., Metivier, B., and Yim, W.W. (2002) Marine reservoir corrections for the Indian Ocean and Southeast Asia. Radiocarbon, 44, 167-180. https://doi.org/10.1017/S0033822200064778

Stanley, D.J. and Warne, A.G. (1993) Nile Delta: recent geologi al _.', lution and human impact. Science, 260 (5108), 628-634. https://doi.org/10.1126/science.zi 7.51$) 8.628$

Stow, D.A. and Mayall, M. (2000) Deep-water sedim $: n^{+} d^{r} y$ systems: New models for the 21st century. Marine and Petroleum Geology, 17, 125-12',. । ttp. '//doi.org/10.1016/S0264-8172(99)00064-1

Stow, D.A.V. and Lovell, J.P.B. (1979) Cor+ourites. their recognition in modern and ancient se diments. Earth-Science Reviews, 14(3), 251-29: , ‘، . s://doi.org/10.1016/0012-8252(79)90002-3

Stow, D.A. and Piper, D.J. (1984) D?t, --water fine-grained sediments: facies models. GeologicalSociety, London, SpecialPublications, 1s, 511-646. https://doi.org/10.1144/GSL.SP.1984.015.01.38

Summerfield, M.A., an. ' HL' ton N.J. (1994). Natural controls of fluvial denudation rates in major w orld drainage basins. J *.nal of Geophysical Research: Solid Earth, 99(B7), 13871-13883. https://doi.org/10.1029/94JB00715

Talbot, M.R. and Johannessen, T. (1992) A high resolution palaeoclimatic record for the last 27,500 years in tropical West Africa from the carbon and nitrogen isotopic composition of lacustrine organic matter. Earth and Planetary Science Letters, 110, 23-37. https://doi.org/10.1016/0012-

$821 X(92) 90036-U$ 
Tanaka, T., Togashi, S., Kamioka, H., Amakawa, H., Kagami, H., Hamamoto, T., Yuhara, M., Orihashi, Y., Yoneda, S., Shimizu, H., Kunimaru, T., Takahashi, K., Yanagi, T., Nakano, T., Fujimaki, H., Shinjo, R., Asahara, Y., Tanimizu, M. and Dragusanu, C. (2000) JNdi-1: a neodymium isotopic reference in consistency with LaJolla neodymium. Chem. Geol., 168, 279-281. https://doi.org/10.1016/S00092541(00)00198-4

Thevenon, F., Williamson, D. and Taieb, M. (2002) A 22 kyr BP sedimentological record of Lake Rukwa ( $8^{\circ} \mathrm{S}$, SW Tanzania): environmental, chronostratigraphic and climati mplications. Palaeogeography, Palaeoclimatology, Palaeoecology, 187, 285-294. https://doi.org, ${ }^{10} 0.1$ )16/S0031-0182(02)00481-9

Thomas, D.S.G. and Shaw, P.A. (1988) Late Cainozoic drai las - ¿volution in the Zambezi basin: Geomorphological evidence from the Kalahari rim. J. Afı - an arth Sci. (and Middle East), 7, 611-618. https://doi.org/10.1016/0899-5362(88)90111-X

Thomas, D., Shaw, P.A. (1991) The Kalahari Er Jırı nnı nt. Cambridge University Press.

Thompson, J.O., Moulin, M., Aslanian, D Guillowheau, F., de Clarens, P. (2019) New starting point for the Indian Ocean: Second phase of $2 r^{\prime}-a^{\prime \prime}$ up for the Gondwana. Earth Science Reviews, 191, 26-56. https://doi.org/10.1016/j.earsc'rt $\cdot 2019.01 .018$

Tierney, J.E., Russell, J.M., Huจng, ' , Damsté, J.S.S., Hopmans, E.C. and Cohen, A.S. (2008) Northern hemisphere control. on 'rop cal southeast African climate during the past 60,000 years. Science, 322, 252-255. https://doi.c ¿/10.1126/science.1160485

Tinterri, R. and Muzzi Magal haes, P. (2011) Synsedimentary structural control on foredeep turbidites: An example from Miocene Marnoso-arenacea Formation, Northern Apennines, Italy. Marine and Petroleum Geology, 28, 629-657. https://doi.org/10.1016/j.marpetgeo.2010.07.007

Toucanne, S., Zaragosi, S., Bourillet, J.-F., Dennielou, B., Jorry, S.J., Jouet, G. and Cremer, M. (2012) External controls on turbidite sedimentation on the glacially-influenced Armorican margin (Bay of 
Biscay, western European margin). Marine Geology, 303, 137-153.

https://doi.org/10.1016/j.margeo.2012.02.008

Toucanne, S., Soulet, G., Freslon, N., Jacinto, R.S., Dennielou, B., Zaragosi, S., Eynaud, F., Bourillet, J.-F. and Bayon, G. (2015) Millennial-scale fluctuations of the European Ice Sheet at the end of the last glacial, and their potential impact on global climate. Quaternary Science Reviews, 123, 113-133. https://doi.org/10.1016/j.quascirev.2015.06.010

Toucanne, S., Zaragosi, S., Bourillet, J.-F., Naughton, F., Cremer, M. Eynaud, F. and Dennielou, B. (2008) Activity of the turbidite levees of the Celtic-Armorican mal in ( 3ay of Biscay) during the last 30,000 years: imprints of the last European deglaciation an 1 hi: irich events. Marine Geology, 247, 84-103. https://doi.org/10.1016/j.margeo.2007.08.006

Trauth, M.H., Maslin, M.A., Deino, A. and Strecker, ' A.'.. (2005) Late cenozoic moisture history of East Africa. Science, 309, 2051-2053. https://dr .01 j/ii 1126/science.1112964

Tripsanas, E.K., Piper, D.J., Jenner, K.A. and Bryarı, W.R. (2008) Submarine mass-transport facies: New

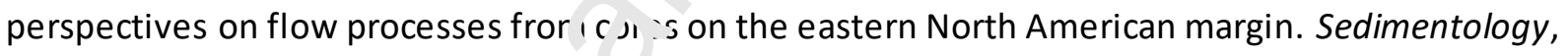
55, 97-136. https://doi.org/10.1..'1/j.1365-3091.2007.00894.x

Vail, P.R., Mitchum, R.M., Jr. ana Thompson, S. (1977) Seismic stratigraphy and global changes of sea level, Part 4, Global ، 'cl s s of elative changes of sea level, in Payton, C.E., ed., Seismic stratigraphyApplications to hydroc. 'Jon exploration: American Association of Petroleum Geologists Memo ir , 26, 83-97.

Van Aken, H.M., Ridderinkhof, H. and de Ruijter, W.P. (2004) North Atlantic deep water in the southwestern Indian Ocean. Deep Sea Research Part I: Oceanographic Research Papers, 51, 755-776. https://doi.org/10.1016/j.dsr.2004.01.008

Van der Lubbe, H.J.L., Frank, M., Tjallingii, R. and Schneider, R.R. (2016) Neodymium isotope constraints on provenance, dispersal, and climate-driven supply of Zambezi sediments along the 
Mozambique Margin during the past $~ 45,000$ years. Geochemistry, Geophysics, Geosystems, 17, 181-198. https://doi.org/10.1002/2015GC006080

Van der Lubbe, H.J.L., Tjallingii, R., Prins, M.A., Brummer, G.-J.A., Jung, S.J.A., Kroon, D. and Schneider, R.R. (2014) Sedimentation patterns off the Zambezi River over the last 20,000years. Marine Geology, 355, 189-201. https://doi.org/10.1016/j.margeo.2014.05.012

Waelbroeck, C., Labeyrie, L., Michel, E., Duplessy, J.C., McManus, J., Lambeck, K., Balbon, E. and Labracherie, M. (2002) Sea-level and deep water temperature chan s $^{\prime}$ s derived from benthic foraminifera isotopic records. Quaternary Science Reviews, 21, 29! -30' . https://doi.org/10.1016/S0277-3791(01)00101-9

Walford, H.L., White N.J. and Sydow, J.C. (2005) Solid sedi, 'ent oad history of the Zambezi Delta. Earth and Planetary Science Letters, 238, 49-63. https:// tc ..crg/10.1016/j.epsl.2005.07.014

Weber, M.E., Wiedicke, M.H., Kudrass, H.R., Fub. cht ; C. and Erlenkeuser, H. (1997) Active growth of the Bengal Fan during sea-level rise ar. 1 highst.nd. Geology, 25, 315-318. https://doi.org/10.1130/0091-7613(1 $79 /$ ר?า5\%3C0315:AGOTBF\%3E2.3.CO;2

Weimer, P. and Link, M.H. (1991) Flobal petroleum occurrences in submarine fans and turbidite systems. In: Weimer P., Link M.' ' (eds) Seismic Facies and Sedimentary Processes of Submarine Fans and Turbidite Sysi?m. F'ontiers in Sedimentary Geology. Springer, New York, NY., 9-67. https://doi.org/10.10C?', J78-1-4684-8276-8_2

Wiles, E., Green, A., Watkeys and M., Jokat, W. (2017a) Zambezi continental margin: compartmentalized sediment transfer routes to the abyssal Mozambique Channel. Mar Geophys Res., 38, 227. https://doi.org/10.1007/s11001-016-9301-4

Wiles, E., Green, A., Watkeys and M., Jokat, W. (2017b) The Zambezi Channel: A new perspective on submarine channel evolution at low latitudes. Geomorphology, 286, 121-132. https://doi.org/10.1016/j.geomorph.2017.02.014 
Wiles, E., Green, A., Watkeys, M., Jokat, W. and Krocker, R. (2013) The evolution of the Tugela canyon and submarine fan: a complex interaction between margin erosion and bottom current sweeping, southwest Indian Ocean, South Africa. Marine and Petroleum Geology, 44, 60-70. https://doi.org/10.1016/j.marpetgeo.2013.03.012

WoldeGabriel, G., Haile-Selassie, Y., Renne, P.R., Hart, W.K., Ambrose, S.H., Asfaw, B., Heiken, G. and White, T. (2001) Geology and palaeontology of the late Miocene Middle Awash valley, Afar rift, Ethiopia. Nature, 412, 175-178. https://doi.org/10.1038/35084058

Zaragosi, S., Bourillet, J.-F., Eynaud, F., Toucanne, S., Denhar A, L , van Toer, A. and Lanfumey, V. (2006) The impact of the last European deglaciation on the dt गp-sea turbidite systems of the CelticArmorican margin (Bay of Biscay). Geo-Marine Letters, 25, - '7-329. https://doi.org/10.1007/s00367006-0048-9

Ziegler, M., Simon, M.H., Hall, I.R., Barker, S., _ 'ringer, C. and Zahn, R. (2013) Development of Middle Stone Age innovation linked to " nia climate change. Nature communications, 4, 1905. https://doi.org/10.1038/ncomm-'89,

\section{FIGURESCAPTIONS}

Fig. 1. (A) General map of southeast Africa illustrating the Zambezi catchment on the African contine nt (delineated with whiteline) including the Rungwe region (Rr), Lake Malawi (LM), Palaeo-Lake Patrick (P) and Lake Makgadikgadi (M). Additionally, the main surface (red) and deep water (blue) circulation present in the Mozambique Channel is indicated (after Schulz et al., 2011; Uenzelmann-Neben et al., 2011; Halo et al., 2014). Abbreviations: AABW=Antarctic Bottom Water, AAIW = Antarctic Intermediate 
Water, $\mathrm{EACC}=$ East African Coastal Current, $\mathrm{MC}=$ Mozambique Current, $\mathrm{MUC}=$ Mozambique Undercurrent, NADW $=$ North Atlantic Deep Water, SEMC $=$ Southern branch of the East Madagascar Current. (B) Bathymetric zoom (GEBCO, 2014) illustrating the Mozambique Channel and study area (dashed rectangle in A). The location of the piston cores used in this study is displayed. Different colors are used to indicate the different coring sites (see legend in figure) from the Zambezi depositional system (ZDS) and Madagascar margin. Additionally, the main topographic features (Zambezi Valley and Tsiribihina Valley, TV) and sediment basins (Intermediate Basin, Mozan' ique Basin) are specified. The dotted red boundaries delineate the extent of the Mozambique Fan s 'bd visions (I:Innerfan; II; Middle fan; III: Outer fan; Kolla et al., 1980a, b). Contour lines are nu: ${ }^{-i e d}$ in meters, spaced at $1000 \mathrm{~m}$ intervals.

Fig. 2. (A) Multibeam bathymetric data (res رlu ion of $100 \mathrm{~m}$ ) of the distal part of the Zambezi Fan showing the location of core MOZ1-KSF3C. MOZ2-.:S11, MOZ1-KSF15 and MOZ4-CS25. (B) Interpretation of bathymetric map illustrating a chann $\left(1-{ }_{2}\right.$ - -2 system at the right hand side of the Zambezi incisions (Fierens et al., 2019). (C) Seismir $\mu$ - ffile MOZ4-SR-234c illustrating the position of core MOZ2-KS11 taken on a channel-levee systom $a_{\text {、 }}$ the right hand side of the Zambezi Valley (position in A) (Jouet and Deville, 2015). (D) CHI ${ }^{\circ} \mathrm{F}$-ofil $\geq s$ 2, 3 and 4 (location in A) showing the location of cores MOZ2-KS11, MOZ1-KSF30 and MOZ4-C־ $־$, respectively.

Fig. 3. (A) CHIRP profile illustrating the distal position of core MOZ2-KSO5 in the Intermediate Basin. (B) Bathymetric map (100 m resolution) indicating the position of the CHIRP profile.

Fig. 4: Selected paleoclimate records from around the Mozambique Channel. (A) The full black line indicates paleoclimate record (leaf wax data $\delta^{13} C_{31}$ ) of Lake Malawi basin demonstrating that eastern 
Africa evolved from a predominantly arid environment with high-frequency variability to generally wetter conditions with more prolonged wet and dry intervals (Johnson et al., 2016). The dashed line indicates plant leaf wax data (ratio of $\mathrm{C}_{31} /\left(\mathrm{C}_{29}+\mathrm{C}_{31}\right)$ n-alkanes) from a marine sediment core that receives terrestrial runoff from the Limpopo River. This data is used as a proxy for aridity by Castañeda et al. (2016). (B) Malawi paleo-lakelevel evolving from frequent low lake levels before ca. 900 ka to fre que nt high lake level conditions after (Lyons et al., 2015). (C) Pretoria Saltpan rainfall data ( $\mathrm{mm} /$ year) from Partridge et al. (1997), which is strongly responsive to changes ir varying austral (DJF) summer insolation at $30^{\circ} \mathrm{S}$ resulting from earth orbital precession. (D) Loca. 'on ff the cores that provided the paleoclimate data in A to $\mathrm{C}$. The location of the study area (dast ea :- _tangle) is also displayed.

Fig. 5: (A) The benthic $\delta^{18} \mathrm{O}$ signatures of various core fr " vhich we determined complete age models. Note that core MOZ1-KS26 denotes the comp sit : re srd from (the twin) cores MOZ1-KS26 and MOZ4CS22 (Table 1). These $\delta^{18} \mathrm{O}$ records are c $r$ rrelateu to the LR04 stack (B) of Lisiecki and Raymo (2005). Glacial Terminations are indicated wit 7 a.. tal T (T1 to T8) and the triangles on top indicate the tie points used to synchronize the iso ${ }^{\prime}$ :- records of the Mozambique Channel to the LR04 stack. Marine isotope substages according t^ Raiı . back et al. (2015).

Fig. 6. Photograph, $\mathrm{X}$-ray picture and grain-size results illustrating hemipelagic $\left(\mathrm{H}_{1}, \mathrm{H}_{2}\right)$ and contouritic facies (C) observed in core MOZ2-CS21 (Zambezi slope, Fig. 1B). D10, D50, D90 is the diameter at $10^{\text {th }}$, $50^{\text {th }}$ and $90^{\text {th }}$ percentile, respectively. Particle size distribution graphs are given on the right, with the position of the samples (in $\mathrm{cm}$ ) specified in the upper right corners, as well with big white dots on the Xray image and black arrows in the grain-size data. Stars in the photograph indicate where ${ }^{14} \mathrm{C}$ ages where obtained (cf. Table 4). Note that the two ages demonstrate that the coarser interval (C), showing both 
inverse- (at the bottom) and normal-grading (at the top) intervals, settled in ca. $13 \mathrm{kyr}$. This excludes the possibility for an instantaneous gravity flow deposit, and supports our interpretation as a contouritic facies.

Fig. 7. Photograph, $X$-ray picture and grain-size results that illustrate the hemipelagite $(H)$ (or contourite sensu lato) facies. This is a detail taken from MOZ2-KS05 (Intermediate Basin, Fig. 1B). This facies corresponds to the yellowish beige facies described in the main te $\cdot$ (Section 5.1) to illustrate the biogenic-dominated sedimentation, i.e., Zambezi Fan in an "off" $m$-de , with very low sedimentation rates, $<2 \mathrm{~cm} / \mathrm{kyr}$ ) at the studied sites. D10, D50, D90 is the $d$ an $:^{-t}-\mathrm{r}$ at $10^{\text {th }}, 50^{\text {th }}$ and $90^{\text {th }}$ percentile, respectively. Particle size distribution graphs are given on $t_{1}$. ? rig it, with the position of the samples (in $\mathrm{cm}$ ) specified in the upper right corners, as well with $\mathrm{I}$ Ig $v$ v'ite dots on the X-ray image and black arrow $\mathrm{s}$ in the grain-size data.

Fig. 8: Core-to-core correlation in depth sc $₫$ f the different sedimentary cores for which accurate age models are determined based on $\mathcal{E}^{1} \smile \mathcal{}$ data. Note that core MOZ1-KS26 denotes the composite record from cores MOZ1-KS26 and $\mathrm{MO}_{\llcorner}{ }^{1}-\mathrm{CS} 22$. Core images are accompanied by stable oxygen isotope profiles, which were $4 \cdot a$ to $d$ efine the correlation. The cores are arranged with increasing distance from the Zambezi Deltá, _xcept the Zambezi Lower Fan and Zambezi Valley sites that have been swapped for ease of data presentation (inset map shows the direction of the cross-section). See legend in figure for further details. Terminations 3,4 and 5 are indicated by a blue, red and green line, respectively. Finally, the different ages found for each core base and corresponding MIS stages are given under the pictures. Note that an olive to dark grey, terrigenous sedimentation dominated on the Mozambique and Madagascar margins, while a yellowish, biogenic-dominated sedimentation characterize the deep, oceanic sedimentary records located in the southern part of the Mozambique 
Channel. The stratigraphic correlations point out to lower sedimentation accumulation rates in the latter region.

Fig. 9: Photograph, total organic content (TOC) and colorimetric (a*) data for cores MOZ2-KS11 and MOZ1-KSF30. For core MOZ1-KSF30 the sediment accumulation rate (SAR) is also illustrated (full line: exact values; dashed line: general trend). Stars indicate where ${ }^{14} \mathrm{C}$ ages were obtained, white e psilons indicate where $\mathrm{Nd}$ isotope ratios were measured. Age estimations are specified for the color transitions. Note that these cores include both the yellowish beige (Figs. 7 and 14) $\circ d$ the olive dark grey (Figs. 12, 13 and 16) hemipelagic facies that we interpret as biogenic- (i.e., ' ' $7 m^{\prime}$ ezi Fan in an "off" mode) and terrigenous-dominated (i.e., Zambezi Fan in an “on” mode) sed mt. ${ }^{-}$„tion, respectively.

Fig. 10: (A) Age versus depth relationships determine fr $r^{\text {the }}$ different cores. The inset graph illustrates the corresponding sediment accumulation rat: $t_{1}$,nds. Note that core MOZ1-KS26 denotes the composite record from cores MOZ1-KS2 and MNZ4-CS22. (B) The reference curve LR04 proposed by Lisiecki and Raymo (2005). Marine isoto se $\iota^{2}$ stages according to Railsback et al. (2015).

Fig. 11: Downcore data of core M爪 72 -KSF15 (Zambezi lower Fan, Fig. 1B) plotted on a depth scale. (A) stable oxygen isotope cirta nd olorimetry L*(lightness). The italic numbers at the top indicate the MIS intervals. (B) XRF Ca/Fe rá. sediment accumulation rate (SAR). (E) Colorimetry a* (red/green). (F) High-resolution photo with the indication $\mathrm{Nd}$ isotope ratios measurements (white epsilons). Note that this core includes both the yellowish beige (Figs. 7 and 14) and the olive dark grey (Figs. 12, 13 and 16) hemipelagicfacies that we interpret as biogenic- (i.e., Zambezi Fan in an "off" mode) and terrigenous-dominated (i.e., Zambezi Fan in an "on" mode) sedimentation, respectively (Fig. 19). 
Fig. 12: Photograph, $X$-ray picture and grain-size results demonstrating fine-grained turbidite $\left(T_{1}, T_{2}, T_{3}\right)$ and hemipelagic $(\mathrm{H})$ facies. This is a core section from MOZ4-CS22 (Intermediate Basin, Fig. 1B). Note that the hemipelagic $(\mathrm{H})$ facies here described corresponds to the olive to dark grey facies used in the main text (Section 5.1) to illustrate the terrigenous-dominated sedimentation, i.e., Zambezi Fan in an "on" mode (with moderate to high sedimentation rates, up to $9 \mathrm{~cm} / \mathrm{kyr}$ at MOZ4-CSF20) at the studie d sites. D10, D50, D90 is the diameter at 10th, 50th and 90th perce, ile, respectively. Particle size distribution graphs are given on the right, with the position of the sar. vle (in $\mathrm{cm}$ ) specified in the upper right corners, as well with big white dots on the X-ray image anu bı-1. arrows in the grain-size data.

Fig 13: Photograph, $\mathrm{X}$-ray picture and grainsize res Itt, -howing another example of a fine-grained turbidite (T) and hemipelagic $\left(\mathrm{H}_{1}, \mathrm{H}_{2}\right)$ facies. Tr. SI. a p.rt of core MOZ2-KSO5 (Intermediate Basin, Fig. 1B). Note that the hemipelagic $\left(\mathrm{H}_{1}, \mathrm{H}_{2}\right)$ faries here described corresponds to the olive to dark grey facie $\mathrm{s}$ used in the main text (Section 5.1) to illı st' a - the terrigenous-dominated sedimentation, i.e., Zambezi Fan in an "on" mode (with moderaı to nigh sedimentation rates, up to $9 \mathrm{~cm} / \mathrm{kyr}$ at MOZ4-CSF20) at the studied sites. D10, D50, $\mathrm{n} 90 \mathrm{I}$ - the diameter at $10^{\text {th }}, 50^{\text {th }}$ and $90^{\text {th }}$ percentile, respectively. Particle size distribution graphs ?re rive I on the right, with the position of the samples (in $\mathrm{cm}$ ) specified in the upper right corners, as $v_{v}-{ }^{\prime}$. with big white dots on the $\mathrm{X}$-ray image and black arrows in the grain-size data.

Fig 14: Photograph, $X$-ray picture and grain-size characterizing hemipelagic $\left(H_{1}, H_{2}\right)$ facies and sandy turbidites (T), found in core MOZ4-CS25 (Zambezi Lower Fan, Fig. 1B). The hemipalgic facies $\left(H_{1}, H_{2}\right)$ corresponds to the yellowish beige facies (i.e., Zambezi Fan in an "off" mode) used in the main text (Section 5.1) to illustrate the biogenic-dominated sedimentation (with very low sedimentation rates, $<2$ 
$\mathrm{cm} / \mathrm{kyr}$ ) at the studied sites. D10, D50, D90 is the diameter at $10^{\text {th }}, 50^{\text {th }}$ and $90^{\text {th }}$ percentile, respectively. Particle size distribution graphs are given on the right, with the position of the samples (in $\mathrm{cm}$ ) specified in the upper right corners, as well with big white dots on the X-ray image and black arrows in the grainsize data. The triangle in the photograph indicates where a nannofossil age was obtained.

Fig. 15: Photograph, X-ray picture and grainsize illustrating the organic rich turbidite (T) found in MOZ2KS11 (Zambezi Valley, Fig. 1B). D10, D50, D90 is the diameter at, th, 50th and 90th percentile, respectively. Particle size distribution graphs are given on the right, $w^{\text {th }} \mathrm{t}^{\prime}$ ' e position of the samples (in $\mathrm{cm}$ ) specified in the upper right corners, as well with big white ( ot_-i the X-ray image and black arrows in the grain-size data.

Fig. 16: Photograph, X-ray picture and grain-si _e c larc-terizing whitish grey carbonate turbidites (T) and hemipelagic $(H)$ facies, found in core MOZ4- ¿S22 (Intermediate Basin, Fig. 1B). Note that the hemipelagic $(\mathrm{H})$ facies here described cc $\mathrm{rr}, \mathrm{s}$, onds to the olive to dark grey facies used in the main text (Section 5.1) to illustrate the terrig?r, us-dominated sedimentation, i.e., Zambezi Fan in an "on" mode (with moderate to high sedimenta، in rates, up to $9 \mathrm{~cm} / \mathrm{kyr}$ at MOZ4-CSF20) at the studied site s. D10, D50, D90 is the diamet $\mathrm{rai}$ 10tr, 50th and 90th percentile, respectively. Particle size distribution graphs are given on the right, wic- ne position of the samples (in $\mathrm{cm}$ ) specified in the upper right corners, as well with big white dots on the X-ray image and black arrows in the grain-size data.

Fig. 17: (A) Pretoria Saltpan rainfall data ( $\mathrm{mm} /$ year) from Partridge et al. (1997) with varying austral (DJF) summer insolation at $30^{\circ} \mathrm{S}$. (B) FE/K record of CD154-10-06P (Simon et al., 2015). The 17-point running mean is specified in black. This ratio indicates more humid climate in accordance with high austral (DJF) summer insolation at $30^{\circ} \mathrm{S}$. (C) XRF Fe/Ca ratio of MOZ4-CSF20 (grey) with its 9-point 
running average (black). Lowervalues of the Fe/Ca ratio observed during MIS 5a, MIS 5c and MIS $5 e$ are mainly due to dilution of carbonate content by an increase of Zambezi terrigenous sediment (Simon et al., 2015). (D) Mass Accumulation Rates (MAR) with error bars for core MOZ4-CSF20 (Zambezi Slope, Fig. 1B). The MAR results shown in green (dashed) are based on an age model where the tie -point for MIS 5 correspond to the $\delta^{18} \mathrm{O}$ substages boundaries, while those in blue have been calculated based on an agemodel for which tie-points correspond to the peaks (i.e., warm substages) and lows (i.e., cold substages) of MIS 5. Note that MAR are significantly higher in the second case, us revealing that MAR are not sensitive to sea-level changes (E) but to local insolation forcing and $m$ nnsr on -related precipitations (A). (E) The benthic $\delta^{18} \mathrm{O}$ signature of core MOZ4-CSF20. In green d ? ihe '.'., ne is the age model with tie-points within MIS 5 put on the boundaries of the substages; the hlu. line is the age model with tie-points located on the peaks of MIS 5 substages. The refer !n _e curve LR04 proposed by Lisiecki and Raymo

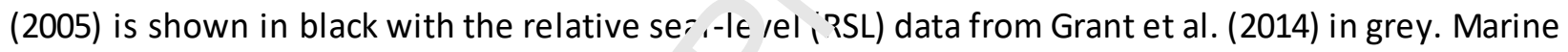
isotope substages according to Railsbac', et al. (2015). The black squares indicate the occurrence of turbidites in MOZ4-CSF20.

Fig. 18: Synthesis of sediment -olor thanges (olive grey - i.e., Zambezi Fan in an "on" mode- to yellowish beige- i.e., Zambezi Fa. ir. an off" mode) and occurrence of turbidites on a time scale for different studied cores for which $a_{0}-s$ were determined. The frequency of turbidites (italic white numbers per MIS stage) is represented with calculated recurrence time (duration each isotope stage -kyr-divided by amount of turbidites per isotope stage) and Gaussian shaped curves (the higher the curves the more turbidites). The black Gaussian curves are siliciclastic turbidites and blue curves are carbonate turbidites. For each core, the small black dots are the exact age of the turbidites and the white epsilons are the $\mathrm{Nd}$ isotope ratio measurements. For the various color transitions age estimations are given. For core MOZ4CS25, the position of obtained biostratigraphic (B.) and radiocarbon dates are illustrated. The refere nce 
curve LR04 proposed by Lisiecki and Raymo (2005) is illustrated at the bottom. Marine isotope substages according to Railsback et al. (2015).

Fig. 19. Schematic interpretation of the evolution of the Zambezi depositional system fed by the Zambezi and Madagascar rivers over the past 720 kyr. (A) Two synthetic profiles ( $a-a^{\prime}$ and b-b', location in B) based on different piston cores (long rectangles) with overview of the sediment color changes (see legend in figure). Trends of progradation (P.) and retrogradation (R.) c e indicated. (B) Distribution of terrigenous-dominated (grey) and biogenic-dominated (orange) facie - in † le Mozambique Channel at two major times: prior and posterior to the major depocenters litı ${ }^{-+} 356 \pm 42 \mathrm{ka}$ (white lines in A).During the period before the shift of depocenter (pre- $356 \pm 42 \mathrm{ka}$, ter igenous supplies occurred in the distal Zambezi Fan (i.e., Zambezi Fan in an "on" mode) as w II "s in the Intermediate Basin. This case may also be valid between $720 \mathrm{ka}$ to $644 \pm 3 \mathrm{ka}$. Th - $\mathrm{p}$ ast after the depocenter shift (post- $356 \pm 42 \mathrm{ka}$ ) is characterized by an increase of detrital inputs tı wards the Intermediate Basin (grey arrows) that has become the unique depocenter for Zam ie $\_$Narived sediments (i.e., "off" mode of the Zambezi Fan) . This case may also be valid betwf $\mathrm{e}_{1}$. ca. $644 \pm 3 \mathrm{ka}$ and $550 \pm 20 \mathrm{ka}$. Marine boundaries (MIS) proposed by Lisiecki and Raymo (2005).

Fig. 20: (A) Nd Isotope vai - s along various cores in the study area (see Table 5 for the exact Nd isotope ratios). Color indicates the colors of sediment where the sample was taken. (B) Reference isotopic curve LR04 (black) proposed by Lisiecki and Raymo (2005) with the relative sea-level (RSL) data from Grant et al. (2014) in grey. (C) Paleoclimate records showing a change from more arid to more humid conditions (grey line). Dashed line: $\delta^{13} C_{31}$ from Johnson et al. (2016); full black line: $C_{31} /\left(C_{29}+C_{31}\right) n$-alkane ratio from Castañeda et al. (2016). 
Table 1: Key parameters of the sediment cores investigated in this study. CS in the core name indicates Calypso coring system, while KS indicates Kullenberg system. Notice that cores MOZ1-KS26 and MOZ4CS22 have been taken at the same location (only $35 \mathrm{~m}$ from each other) and have been combined to establish a composite core. IGSN = International Geo Sample Number with hyperlink to where core data related to this article can be requested.

Table 2: Characteristics of the different lithofacies. Examples of the 1 cies are shown in figures 6 to 7 and 12 to 16.

Table 3: Radiocarbon dates from the Mozambique Channei.

Table 4: Control points used to fit $\delta^{18} O$ record ot he ''ifferent cores for which we determined complete age models by comparing to the LR04-stack of Lisıcki and Raymo (2005). Isotopic events as defined by Railback et al. (2015). Depths shown bet $N$ r. $\cdot$ - parentheses re present an isotopic event that is not used as control point in a particular core . 1 is level has been determined by interpolation between adjacent levels.

Table 5: Nd isotope ratios $\ldots 1$ d corresponding age (ka) for different cores from the Mozambique Channel. 


\begin{tabular}{|c|c|c|c|c|c|c|c|}
\hline Core ID & Cruise & $\begin{array}{l}\text { Research } \\
\text { vessel }\end{array}$ & Latitude, $\mathbf{S}$ & $\begin{array}{l}\text { Longitude, } \\
\text { E }\end{array}$ & $\begin{array}{l}\text { Depth } \\
(\mathbf{m})\end{array}$ & $\begin{array}{l}\text { Core length } \\
(\mathbf{m})\end{array}$ & IGSN \\
\hline \multicolumn{8}{|l|}{ Zambezi Slope } \\
\hline MOZ4-CSF20 & PAMELA-MOZ4 & Pourquoi Pas? & $18^{\circ} 26.786^{\prime}$ & $39^{\circ} 55.896^{\prime}$ & 2,501 & 9.90 & $\begin{array}{c}\text { BFBGX-128005 } \\
\text { http://igsn.org/BFBGX-128005 }\end{array}$ \\
\hline MOZ4-CS21 & PAMELA-MOZ4 & Pourquoi Pas? & $19^{\circ} 20.313^{\prime}$ & $40^{\circ} 46.702^{\prime}$ & 3,036 & 10.54 & $\begin{array}{c}\text { BFBGX-128006 } \\
\text { http://igsn.org/BFBGX-128006 }\end{array}$ \\
\hline \multicolumn{8}{|c|}{ Zambezi Intermediate Basin } \\
\hline MOZ1-KS26 & PAMELA-MOZ1 & L'Atalante & $21^{\circ} 16.434^{\prime}$ & $39^{\circ} 55.863^{\prime}$ & 3,095 & 8.99 & $\begin{array}{c}\text { BFBGX-127682 } \\
\text { http://igsn.org/BFBGX-127682 }\end{array}$ \\
\hline MOZ4-CS22 & PAMELA-MOZ4 & Pourquoi Pas? & $21^{\circ} 16.441^{\prime}$ & $39^{\circ} 55.878^{\prime}$ & 3,099 & 15.25 & $\begin{array}{c}\text { BFBGX-128007 } \\
\text { http://igsn.org/BFBGX-128007 }\end{array}$ \\
\hline MOZ2-KS05 & PAMELA-MOZ2 & L'Atalante & $21^{\circ} 27.606^{\prime}$ & $40^{\circ} 43.075^{\prime}$ & 3,09 ? & 8.59 & $\begin{array}{c}\text { BFBGX-127456 } \\
\text { http:///gsn.org/BFBGX-127456 }\end{array}$ \\
\hline \multicolumn{8}{|l|}{ Zambezi Valley } \\
\hline MOZ1-KSF30 & PAMELA-MOZ1 & L'Atalante & $25^{\circ} 25.602^{\prime}$ & $41^{\circ} 35.723^{\prime}$ & $41^{7} 8$ & 8.59 & $\begin{array}{c}\text { BFBGX-81403 } \\
\text { http:///gsn.org/BFBGX-81403 }\end{array}$ \\
\hline MOZ2-KS11 & PAMELA-MOZ2 & L'Atalante & $25^{\circ} 33.989^{\prime}$ & $41^{\circ} 36.989^{\prime}$ & 4,131 & 7.60 & $\begin{array}{c}\text { BFBGX-127461 } \\
\text { http://igsn.org/BFBGX-127461 }\end{array}$ \\
\hline \multicolumn{8}{|c|}{ Zambezi Lower Fan } \\
\hline MOZ4-CS25 & PAMELA-MOZ4 & Pourquoi Pas? & $26^{\circ} 37.318^{\prime}$ & $44^{\circ} 17.148^{\prime}$ & 4,388 & 4.21 & $\begin{array}{c}\text { BFBGX-128010 } \\
\text { http://igsn.org/BFBGX-128010 }\end{array}$ \\
\hline MOZ2-KSF15 & PAMELA-MOZ2 & L'Atalante & $26^{\circ} 24.691^{\prime}$ & $40^{\circ} 1 / .279^{\prime}$ & 4,415 & 13.13 & $\begin{array}{c}\text { BFBGX-127451 } \\
\text { http://1gsn.org/BFBGX-127451 }\end{array}$ \\
\hline \multicolumn{8}{|c|}{ Madagascar Margin } \\
\hline MOZ1-KSF24 & PAMELA-MOZ1 & L'Atalante & $21^{\circ} \mathrm{S}: 100^{\prime}$ & $41^{\circ} 51.672^{\prime}$ & 3,089 & 8.59 & $\begin{array}{c}\text { BFBGX-127680 } \\
\text { http://igsn.org/BFBGX-127680 }\end{array}$ \\
\hline MOZ2-KSF13 & PAMELA-MOZ2 & L'Atalante & $2 \epsilon^{\circ} 00^{\prime} .480^{\prime}$ & $42^{\circ} 16.474^{\prime}$ & 4,149 & 7.29 & $\begin{array}{c}\text { BFBGX-127449 } \\
\text { http://igsn.org/BFBGX-127449 }\end{array}$ \\
\hline
\end{tabular}


Facies

Description
D10

$(\mu \mathrm{m})$
D50

$(\mu \mathrm{m})$
D90

$(\mu \mathrm{m})$
Occurrence

0.2-10 8-396 90-1080 Ubiquitous

Core

Homogenous foraminiferal ooze to carbonate mud with yellowish beige or olive grey color. Common mottled appearance due to intense bioturbation. Few $\mathrm{cm}$ - to several m-thick. This facies can be interpreted as a contourite sensu lato considering the ubiquity of All geostrophic bottom currents in the Mozambique Channel.

Inversely to massive graded sandy clay with dark grey color. Poorly sorted, fine to coarse sand fraction (20\%) that consists of quartz, mica and foraminifera. Occasionally, clasts of lithified sediment and quartz pebbles occur (diameter: 0.4 to $2 \mathrm{~cm}$ ). Meter-thick.

Normal graded beds with dark grey color. The base shows medium sand to silty clay with quartz, mica and 1.6-2 $\quad$ 205-565 Zambezi Slope

MOZ4-CS21 (Fig. 6) foraminifera. Pluri-millimetric, horizontal or oblique laminations may be present. The upper part comprises structureless mud. Commonly intense bioturbation $(\leq 20$ $\mathrm{cm}$ ) creates pockets of foraminiferal mud. Flat to undulating erosional base. $\mathrm{Cm}$ - to $\sim 0.5 \mathrm{~m}$-thick.

Massive to normal graded sand beds. Fine to very fine

Fine-grained turbidites

(Fig. 12, 13) sand fraction that consist of quartz $(90 \%)$, feldspar and

Sandy turbidites mica. Millimetric lamination may be present. (Fig. 14) Bioturbation at the top is less common. Erosive $v \ldots \mathrm{v}$ base. Few cm to $\sim 1$ m-thick.

Organic-rich turbidites (Fig. 15) Massive organic-rich bed with highly black ce or. Contains much pyrite and pyritised wood ragments (diameter: $<2 \mathrm{~cm}$ ). Changes irregularly at the to $\boldsymbol{i}_{\mathbf{i}}$ into massive clay. Erosive base. Decimeter-thick.

Massive to normal graded carbonate ber.s vil. whitish

Carbonate turbidites (Fig. 16) color. Moderately sorted, very fine to oarse grained fraction with coral debris, forani ifera and shell fragments. Horizontal to wavy lam. atun is common. Detrital grains are occasionally ?res ənt. Erosive flat base. $\mathrm{Cm}$ - to $\sim 0.5 \mathrm{~m}$-thick.

\begin{tabular}{|c|c|c|c|c|}
\hline $1.6-2$ & $18-54$ & $205-565$ & Zambezi Slope & MOZ4-CS21 \\
\hline $1-44$ & -175 & $22-740$ & $\begin{array}{l}\text { Zambezi Slope, } \\
\text { Zambezi Int. Basin, } \\
\text { Zambezi Valley and } \\
\text { Madagascar Margin }\end{array}$ & $\begin{array}{c}\text { MOZ1-KSF30 } \\
\text { MOZ1-KSF24 } \\
\text { MOZ2-KSF13 } \\
\text { MOZ1-KS26 } \\
\text { MOZ4-CS22 } \\
\text { MOZ2-KS05 } \\
\text { MOZ4-CSF20 }\end{array}$ \\
\hline,-7 & $54-239$ & $124-689$ & $\begin{array}{c}\text { Zambezi Valley, } \\
\text { Madagascar Margin } \\
\text { and Zambezi Lower } \\
\text { Fan }\end{array}$ & $\begin{array}{l}\text { MOZ2-KS11 } \\
\text { MOZ4-CS25 }\end{array}$ \\
\hline $2-18$ & $10-163$ & $66-1200$ & Zambezi Valley & MOZ2-KS11 \\
\hline $4-53$ & $154-620$ & $337-1370$ & $\begin{array}{c}\text { Zambezi Int. Basin } \\
\text { and Madagascar } \\
\text { Margin }\end{array}$ & $\begin{array}{c}\text { MOZ1-KS26 } \\
\text { MOZ4-CS22 } \\
\text { MOZ2-KSF13 } \\
\text { MOZ1-KSF24 }\end{array}$ \\
\hline
\end{tabular}




\begin{tabular}{|c|c|c|c|c|c|c|c|c|c|c|}
\hline Core label & $\begin{array}{l}\text { Depth } \\
(\mathrm{cm})\end{array}$ & Lab. Number & Species & $\begin{array}{l}{ }^{14} \mathrm{C} \text { age } \\
\text { (yr BP) }\end{array}$ & $\begin{array}{l}\text { error } \\
(1 \sigma)\end{array}$ & $\begin{array}{c}\text { Reservoir } \\
\text { correction }^{\mathrm{a}} \\
{ }^{\left.1{ }^{14} \mathrm{C} \text { yr }\right)}\end{array}$ & $\begin{array}{l}\text { errora }^{a} \\
(1 \sigma)\end{array}$ & $\begin{array}{l}{ }^{14} \mathrm{C} \text { age } \\
\text { corrected } \\
\quad \text { for } \\
\text { reservoirb } \\
\text { ( }{ }^{14} \mathrm{C} \text { yr BP) }\end{array}$ & $\begin{array}{l}\text { errorc } \\
(1 \sigma)\end{array}$ & $\begin{array}{c}\text { Calendar age } \\
\text { range }^{d} \\
(y r B P, 2 \sigma)\end{array}$ \\
\hline MOZ1-KSF24 & 0 & Beta-411047 & G. ruber & 4050 & 30 & 426 & 76 & 3624 & 82 & $3701-4153$ \\
\hline MOZ1-KSF24 & 19 & Beta-411048 & G. ruber & 14510 & 50 & 426 & 76 & 14084 & 91 & $16802-17448$ \\
\hline MOZ1-KSF24 & 30 & Beta-406071 & G. ruber & 15890 & 50 & 426 & 76 & 15464 & 91 & 18541-18906 \\
\hline MOZ1-KSF24 & 51 & Beta-406072 & G. ruber & 19160 & 70 & 426 & 76 & 18734 & 103 & $22390-22877$ \\
\hline MOZ1-KSF24 & 60 & Beta-409929 & G. ruber & 22810 & 90 & 426 & 76 & 22384 & 118 & $26289-27087$ \\
\hline MOZ1-KSF30 & 9 & Beta-456709 & bulk planktic & 20590 & 60 & 426 & 76 & 20164 & 97 & $23968-24491$ \\
\hline MOZ1-KSF30 & 59 & Beta-456710 & bulk planktic & 41940 & 650 & 426 & 76 & 41514 & 654 & $43696-46065$ \\
\hline MOZ2-KS05 & 0 & Beta-411049 & G. ruber & 3560 & 30 & 426 & .5 & 3134 & 82 & $3156-3561$ \\
\hline MOZ2-KS05 & 5 & Beta-406067 & G. ruber & 4500 & 30 & 426 & & 4074 & 82 & $4410-4834$ \\
\hline MOZ2-KS05 & 61 & Beta-406068 & G. ruber & 13970 & 40 & 426 & $\tau_{0}$ & 13544 & 86 & $16046-16622$ \\
\hline MOZ2-KS05 & 91 & Beta-448774 & G. ruber & 25020 & 100 & 42, & 76 & 24594 & 126 & $28328-28913$ \\
\hline MOZ2-KS05 & 130 & Beta-409930 & G. ruber & 42750 & 640 & $4^{25}$ & 76 & 42324 & 644 & $44464-46854$ \\
\hline MOZ2-KS11 & 16 & Beta-448773 & G. ruber & 16700 & 50 & $4 \bar{\Upsilon} 6$ & 76 & 16274 & 91 & $19402-19950$ \\
\hline MOZ2-KS11 & 32 & Beta-448772 & G. ruber & 22660 & 80 & +26 & 76 & 22234 & 110 & $26116-26867$ \\
\hline MOZ2-KSF13 & 20 & Beta-406069 & G. ruber & 9460 & $x$ & 426 & 76 & 9034 & 82 & 9909-10405 \\
\hline MOZ2-KSF13 & 42 & Beta-406070 & G. ruber & 16610 & 0 & 426 & 76 & 16184 & 91 & $19242-19813$ \\
\hline MOZ2-KSF13 & 60 & Beta-411050 & G. ruber & $2, ?$ & 150 & 426 & 76 & 29484 & 168 & $33348-34009$ \\
\hline MOZ2-KSF13 & 107 & Beta-409931 & G. ruber & 43,00 & - & - & - & - & - & - \\
\hline MOZ4-CSF20 & 10 & Beta-456712 & bulk plankti & $200 \bar{i}$ & 30 & 426 & 76 & 1634 & 82 & $1350-1714$ \\
\hline MOZ4-CSF20 & 37 & Beta-456713 & bulk planktic & 3410 & 30 & 426 & 76 & 2984 & 82 & $2943-3370$ \\
\hline MOZ4-CSF20 & 104 & Beta-493325 & bulk plank ic & 8880 & 30 & 426 & 76 & 8454 & 82 & 9264-9555 \\
\hline MOZ4-CSF20 & 229 & Beta-493327 & bulk p'an ${ }^{\prime}+\mathrm{ic}$ & 27450 & 120 & 426 & 76 & 27024 & 142 & $30851-31264$ \\
\hline MOZ4-CS21 & 1 & Beta-456703 & $\bar{C} r_{\iota} \overline{\text { 'ver }}$ & 2960 & 30 & 426 & 76 & 2534 & 82 & $2363-2759$ \\
\hline MOZ4-CS21 & 10 & Beta-456704 & rilk, lanktic & 10180 & 60 & 426 & 76 & 9754 & 97 & 10764-11359 \\
\hline MOZ4-CS21 & 40 & Beta-456705 & bulk rlanktic & 23240 & 100 & 426 & 76 & 22814 & 126 & $26774-27459$ \\
\hline MOZ4-CS21 & 71 & Beta-456 & buık planktic & 36420 & 380 & 426 & 76 & 35994 & 388 & $39776-41436$ \\
\hline MOZ4-CS21 & 307 & Beta-ц $56 ハ 7$ & Julk planktic & 28810 & 140 & 426 & 76 & 28384 & 159 & $31685-32863$ \\
\hline MOZ4-CS21 & 424 & Beta-456ハ 8 & bulk planktic & 43390 & 820 & 426 & 76 & 42964 & 824 & $44724-48022$ \\
\hline MOZ4-CS25 & 80 & Beta-44/y35 & bulk planktic & $>43500$ & - & - & - & - & - & - \\
\hline MOZ4-CS26 & 138 & Beta-456711 & bulk planktic & 8810 & 30 & 426 & 76 & 8384 & 82 & 9232-9532 \\
\hline
\end{tabular}

a: Reservoir correction inferred from Southon et al. (2002) and calculated according to Soulet (2015).

b: Corrected ${ }^{14} \mathrm{C}$ ages are obt ained by subtracting the reservoir correction to the original ${ }^{14} \mathrm{C}$ age

c: Errors associated to the corrected ${ }^{14} \mathrm{C}$ were propagated through the quadratic sum

d: Corrected ${ }^{14} \mathrm{C}$ ages were then calibrated using the atmospheric calibration curve IntCal13 (Reimer et al., 2013) 


\begin{tabular}{|c|c|c|c|c|c|c|c|c|c|c|c|}
\hline \multirow{2}{*}{$\begin{array}{c}\text { Termin- } \\
\text { ations }\end{array}$} & \multirow{2}{*}{$\begin{array}{l}\text { Isotopic } \\
\text { events }\end{array}$} & \multirow{2}{*}{$\begin{array}{l}\text { Age } \\
(\mathbf{k a})^{*}\end{array}$} & \multicolumn{9}{|c|}{ Depth in core $(\mathrm{cm})$} \\
\hline & & & $\begin{array}{c}\text { MOZ2- } \\
\text { KS05 }\end{array}$ & $\begin{array}{l}\text { MOZ1 } \\
-K S 26\end{array}$ & $\begin{array}{l}\text { MOZ4 } \\
- \text { CS22 }\end{array}$ & $\begin{array}{l}\text { MOZ2 } \\
-K S 11\end{array}$ & $\begin{array}{l}\text { MOZ1- } \\
\text { KSF24 }\end{array}$ & $\begin{array}{l}\text { MOZ2- } \\
\text { KSF13 }\end{array}$ & $\begin{array}{l}\text { MOZ2- } \\
\text { KSF15 }\end{array}$ & $\begin{array}{l}\text { MOZ1- } \\
\text { KSF30 }\end{array}$ & $\begin{array}{l}\text { MOZ4- } \\
\text { CSF20 }\end{array}$ \\
\hline \multirow[t]{8}{*}{$\mathrm{T} 1$} & $1 / 2$ & 14 & 68 & 70 & - & (13) & 12 & 31 & 24 & 7 & 135 \\
\hline & $2 / 3$ & 29 & $(131)$ & (117) & - & (14) & (63) & (57) & (53) & (12) & 224 \\
\hline & $3 / 4$ & 57 & $(216)$ & $(211)$ & - & (118) & (149) & (139) & $(106)$ & (21) & 427 \\
\hline & $4 / 5$ & 71 & 227 & 255 & - & 178 & 193 & 167 & 133 & (25) & 508 \\
\hline & $5 a / 5 b$ & 85 & (269) & (289) & - & (204) & $(225)$ & $(200)$ & (149) & (34) & 593 \\
\hline & $5 b / 5 c$ & 92 & (330) & (334) & - & $(218)$ & $(244)$ & $(2,7)$ & (158) & (36) & 635 \\
\hline & $5 c / 5 d$ & 106 & $(346)$ & (393) & - & $(245)$ & $(273)$ & $\left(2^{5} 3\right)$ & $(174)$ & (43) & 707 \\
\hline & $5 \mathrm{~d} / 5 \mathrm{e}$ & 116 & $(381)$ & $(427)$ & - & $(287)$ & $(2,4)$ & $(296)$ & $(186)$ & $(47)$ & 783 \\
\hline \multirow[t]{4}{*}{$\mathrm{T} 2$} & $5 / 6$ & 130 & 397 & 461 & - & 313 & 3.9 & 347 & 202 & 53 & 873 \\
\hline & $6 / 7$ & 191 & 528 & 696 & - & (419) & $5: 1$ & (498) & 323 & (123) & - \\
\hline & $7 \mathrm{c} / 7 \mathrm{~d}$ & 220 & 576 & (753) & - & & 558 & $(580)$ & (351) & (156) & - \\
\hline & $7 \mathrm{~d} / 7 \mathrm{e}$ & 234 & $(624)$ & (787) & & $(4 ১ 0)$ & $(606)$ & $(608)$ & 365 & (172) & - \\
\hline \multirow[t]{4}{*}{ T3 } & $7 / 8$ & 243 & 637 & 805 & 803 & 493 & 623 & 632 & 380 & 193 & - \\
\hline & $8 / 9$ & 280 & (643) & - & (952) & 579 & (641) & $(705)$ & 431 & 220 & - \\
\hline & $9 a / 9 b$ & 290 & $(645)$ & & 977 & 602 & (646) & (726) & $(453)$ & (235) & - \\
\hline & $9 \mathrm{~d} / 9 \mathrm{e}$ & 318 & $(650)$ & & (1032) & 614 & (659) & - & (514) & (282) & - \\
\hline \multirow[t]{2}{*}{$\mathrm{T} 4$} & $9 / 10$ & 337 & 65 & - & 1080 & 694 & 690 & - & 555 & 310 & - \\
\hline & $10 / 11$ & 374 & 61 & - & (1155) & (739) & - & - & $(623)$ & (415) & - \\
\hline \multirow[t]{2}{*}{ T5 } & $11 / 12$ & 424 & ,75 & - & 1263 & - & - & - & 715 & 546 & - \\
\hline & $12 / 13$ & 478 & 688 & - & 1457 & - & - & - & 910 & 764 & - \\
\hline \multirow[t]{2}{*}{ T6 } & $13 / 14$ & 533 & 703 & - & - & - & - & - & 1014 & 835 & - \\
\hline & $14 / 15$ & 563 & 707 & - & - & - & - & - & 1075 & - & - \\
\hline \multirow[t]{2}{*}{$\mathrm{T} 7$} & $15 / 16$ & 621 & 730 & - & - & - & - & - & 1153 & - & - \\
\hline & $16 / 17$ & 676 & $(748)$ & & & & & & (1281) & & \\
\hline \multirow[t]{2}{*}{ T8 } & $17 / 18$ & 712 & 760 & - & - & - & - & - & - & - & - \\
\hline & $18 / 19$ & 760 & - & - & - & - & - & - & - & - & - \\
\hline
\end{tabular}




\section{Journal Pre-proof}

T9

$19 / 20 \quad 790$

Age (ka) at core base

718

248

504

375

357

290

690

536

162

*: Ages based on MIS boundaries proposed by Lisiecki and Ray mo (2005) 


\begin{tabular}{|c|c|c|c|c|}
\hline Core ID & $\begin{array}{l}\text { Depth in } \\
\text { core }(\mathrm{cm})\end{array}$ & Age (ka) & ${ }^{143} \mathrm{Nd} /{ }^{144} \mathrm{Nd} \pm 2 \mathrm{se}$ & $\varepsilon_{\mathrm{Nd}} \pm 2 \mathrm{sd}$ \\
\hline MOZ1-KSF30 & 14 & 35.9 & $0.511956 \pm 0.000004$ & $-13.16 \pm 0.21$ \\
\hline MOZ1-KSF30 & 200 & 255.3 & $0.511946 \pm 0.000006$ & $-13.33 \pm 0.21$ \\
\hline MOZ1-KSF30 & 387 & 364.7 & $0.511575 \pm 0.000005$ & $-20.57 \pm 0.21$ \\
\hline MOZ1-KSF30 & 650 & 453.5 & $0.511928 \pm 0.000005$ & $-13.69 \pm 0.21$ \\
\hline MOZ1-KSF30 & 755 & 476.0 & $0.511915 \pm 0.000004$ & $-13.95 \pm 0.21$ \\
\hline MOZ2-KS05 & 49 & 6.0 & $0.511650 \pm 0.000004$ & $-19.12 \pm 0.21$ \\
\hline MOZ2-KS05 & 170 & 36.3 & $0.511818 \pm 0.0000 v_{4}$ & $-15.84 \pm 0.21$ \\
\hline MOZ2-KS05 & 470 & 182.9 & $0.511894 \pm 0.06$ `04 & $-14.37 \pm 0.21$ \\
\hline MOZ2-KS05 & 682 & 453.1 & $0.511938 \pm$ inor J03 & $-13.50 \pm 0.21$ \\
\hline MOZ2-KS05 & 739 & 648.3 & $0.51 .93, \pm 6.000005$ & $-13.52 \pm 0.21$ \\
\hline MOZ2-KS11 & 668 & 319.6 & $0.5185,+0.000003$ & $-15.05 \pm 0.21$ \\
\hline MOZ2-KSF13 & 90 & 45.9 & $0.5 .1925 \pm 0.000004$ & $-13.76 \pm 0.21$ \\
\hline MOZ2-KSF13 & 480 & $1,6.2$ & $0.511911 \pm 0.000006$ & $-14.03 \pm 0.21$ \\
\hline MOZ2-KSF13 & 664 & 265.1 & $0.511921 \pm 0.000004$ & $-13.82 \pm 0.21$ \\
\hline MOZ2-KSF15 & 60 & $3\llcorner .8$ & $0.511979 \pm 0.000005$ & $-12.70 \pm 0.21$ \\
\hline MOZ2-KSF15 & 403 & 259.7 & $0.511927 \pm 0.000004$ & $-13.72 \pm 0.21$ \\
\hline MOZ2-KSF15 & & 459.7 & $0.511935 \pm 0.000005$ & $-13.57 \pm 0.21$ \\
\hline MOZ2-KSF15 & $11 \%$ & 640.4 & $0.512002 \pm 0.000004$ & $-12.24 \pm 0.21$ \\
\hline MOZ2-K ' 1 1: & 1295 & 682.2 & $0.511883 \pm 0.000004$ & $-14.57 \pm 0.21$ \\
\hline MOZ1-KS?6 & 31 & 5.2 & $0.511909 \pm 0.000005$ & $-14.06 \pm 0.21$ \\
\hline MOZ1-KS26 & 136 & 34.4 & $0.511873 \pm 0.000004$ & $-14.77 \pm 0.21$ \\
\hline MOZ1-KS26 & 660 & 181.6 & $0.511858 \pm 0.000006$ & $-15.06 \pm 0.21$ \\
\hline MOZ4-CS22 & 862 & 258.0 & $0.511940 \pm 0.000005$ & $-13.46 \pm 0.21$ \\
\hline MOZ4-CS22 & 1105 & 349.5 & $0.511891 \pm 0.000006$ & $-14.42 \pm 0.21$ \\
\hline MOZ4-CS22 & 1353 & 453.3 & $0.511913 \pm 0.000004$ & $-13.98 \pm 0.21$ \\
\hline
\end{tabular}




\section{Declaration of interests}

$\bigotimes$ The authors declare that they have no known competing financial interests or personal relationships that could have appeared to influence the work reported in this paper.

$\square$ The authors declare the following financial interests/personal relationships which may be considered as potential competing interests: 


\section{Journal Pre-proof}

\section{Highlights}

- Chronostratigraphicrecord of the Zambezi turbidite system over the last $\sim 700 \mathrm{kyr}$

- Monsoon-related precipitation drives the riverine inputs in the Zambezi system

- No genetic link between turbidite deposition and climate / sea-level changes in the deep system

- A major distal-to-proximal depocenter shift is recognized at ca. $350 \mathrm{ka}$. 